\title{
Inflammatory Microenvironment of Acute Myocardial Infarction Prevents Regeneration of Heart with Stem Cells Therapy
}

\author{
Saeed Khodayaria,b,c Hamid Khodayaria,b,c Ali Zahedi Amirid,e Maryam Eslami ${ }^{f}$ \\ Dariush Farhudg,h Jürgen Hescheler ${ }^{b, i}$ Karim Nayernia ${ }^{b, c, g}$
}

\begin{abstract}
aCancer Research Center, Tehran University of Medical Sciences, Tehran, Iran, 'International Stem Cell Academy, Cologne/Düsseldorf, Germany, International Center for Personalized Medicine, Düsseldorf, Germany, 'Department of Medical Microbiology and Infectious Diseases, University of Manitoba, Winnipeg, MB, Canada, eManitoba Centre for Proteomics and Systems Biology, Winnipeg, MB, Canada, ${ }^{\mathrm{f} A p p l i e d ~ B i o t e c h n o l o g y}$ Research Center, Tehran Medical Sciences Branch, Islamic Azad University, Tehran, Iran, 9Farhud-Nayernia Group for Genomics Medicine, Farhud Clinic for Medical Genetics, Tehran, Iran, hSchool of Public Health, Tehran University of Medical Science, Tehran, Iran, IInstitute of Neurophysiology, University of Cologne, Cologne, Germany
\end{abstract}

\section{Key Words}

Acute myocardial infarction • Inflammatory microenvironment • Stem cell therapy

\begin{abstract}
Over the past years, the benefits of stem cell therapy approach for treatment of the cardiovascular diseases have been shown through the rebuilding of new cardiomyocytes and blood vessels. while a successful regeneration of the myocardium has been proven on the animal models of acute myocardial injuries resulted from the stem cells transplantation, no significant long-term regenerative with autologous stem cell therapy in patients with acute myocardial infarction have been reported based on recent meta-analyses. It seems that the inflammatory microenvironment of acute myocardial infarction has an inhibitory effect on the stem cells potential for regenerating the injured myocardium. Secretion of critical cytokines with pro-inflammatory properties including tumor necrosis factor- $\alpha$, interleukin- $1 \beta$, and interleukin- 6 as well as induction of hypoxic condition and finally formation of cytotoxic elements cause the cellular death and hinder the stem cells proliferation and differentiation. Based on the evidence, application of some approaches like co-delivery of mesenchymal stem cells with the other useful cells, using the stem cells derived productions, administration of preconditioned and modified cells, and also using the anti-inflammatory agents besides the cell therapy are hypothesized as the primary developed safe and practical approaches for

S. Khodayari and H. Khodayari contributed equally to this work.




\section{Cellular Physiology Cell Physiol Biochem 2019;53:887-909 \\ \begin{tabular}{ll|l} 
and Biochemistry $10.33594 / 000000180$ & C) 2019 The Author(s). Published by \\
Published online: 22 November 2019 & Cell Physiol Biochem Press GmbH\&Co. KG
\end{tabular} \\ Khodayari et al.: AMI Microenvironment: SCs Death \& Regeneration}

decreasing destructive effects of the inflammation on the implanted stem/progenitor cells. In this review, we critically discuss the quiddity of the inflammatory microenvironment and its promoted mechanisms as the main elements to hinder the efficacy of stem cell therapy in the cases of acute myocardial infarction. Also, we finally propose some applied solutions to the problem of cardiac regeneration with stem cells therapy.

(C) 2019 The Author(s). Published by Cell Physiol Biochem Press GmbH\&Co. KG

\section{Introduction}

Recent epidemiological reports have demonstrated acute myocardial infarction (AMI) includes wide varieties of cardiovascular diseases (CVDs), which are the main causes of death among human populations [1]. Over the past decade, stem cells (SCs) have shown great promise for the regeneration of the injured heart tissue. In several clinical trials, cardioprotective and regenerative potentials of the SCs were studied among the AMI patients [2-5]. More specifically, different types of pluripotent stem cells (PSCs) and adult stem/ progenitor cells (ASPCs) have been proven to have heart regeneration potential and the ability for generating the myocardium cells lineages such as cardiomyocytes (CMCs), vascular smooth muscle cells (VSMC), and vascular endothelial cells (VECs). Moreover, the paracrine/ autocrine release from the implanted SCs into the injured cardiac microenvironment is believed to be another cardioprotective function of the implanted SCs [6, 7].

According to previous published systematic review and meta-analysis, SCs-based therapy in patients with AMI did not contribute to long-term efficiency for improving the heart's injury [8]. The results of this meta-analysis highlight the complex microenvironment of the AMI and the interaction of its components with implanted SCs. During the early phases of the MI, secretion of pro-inflammatory cytokines and recruitment of immune cells in response to hypoxic cells and injured myocardium generate the inflammatory microenvironment of the AMI $[9,10]$. Production of the main pro-inflammatory cytokines like tumor necrotic factor- $\alpha$ (TNF- $\alpha$ ), interleukin-1 $\beta$ (IL-1 $\beta$ ), and interleukin-6 (IL-6) into an infarcted tissue can induce CMCs degeneration via stimulation of apoptotic, necroptosis, and autophagy cascades [1113]. On the other hand, hindering cardiac lineage differentiation of the transplanted SCs in response to these pro-inflammatory cytokines has been reported as another disruptive function of AMI's inflammatory microenvironment [14].

We believe that regulating the complex cytokine network of AMI as well as optimizing the SCs against such a stressful condition might be a safe and efficient approach for increasing the efficiency of the SCs-based therapy in AMI cases. The present review aims to introduce the inflammatory microenvironment in AMI as the critical barrier to heart SCs-based therapy and to offer some important safe and viable methods for overcoming these challenges.

\section{Stem cells in the acute myocardial infarction cell therapy}

Generally, SCs have been introduced as undifferentiated cell populations existing in all stages of mammalian development and show self-renewal capacity. These cells are capable of producing same cellular states through symmetrical and asymmetrical division. SCs could also potentially generate all cell lineages belong to developing and somatic tissues $[15,16]$. Several types of human pluripotent and adult SCs with cardiogenic potential have been isolated so far and were utilized during various pre-clinical and clinical trials (Fig. 1). We focus on the most studied human SCs and their biology.

\section{Pluripotent Stem Cells}

Embryonic stem cells (ESCs), which are directly isolated from the mammalian blastocyst inner cell mass (ICM), represent the first well-known PSCs [16]. The pluripotent state of the ESCs is primarily controlled by expression of several core transcription factors such as octamer-binding transcription factor 4 (Oct4), sex determining region Y-box 2 (Sox2), 


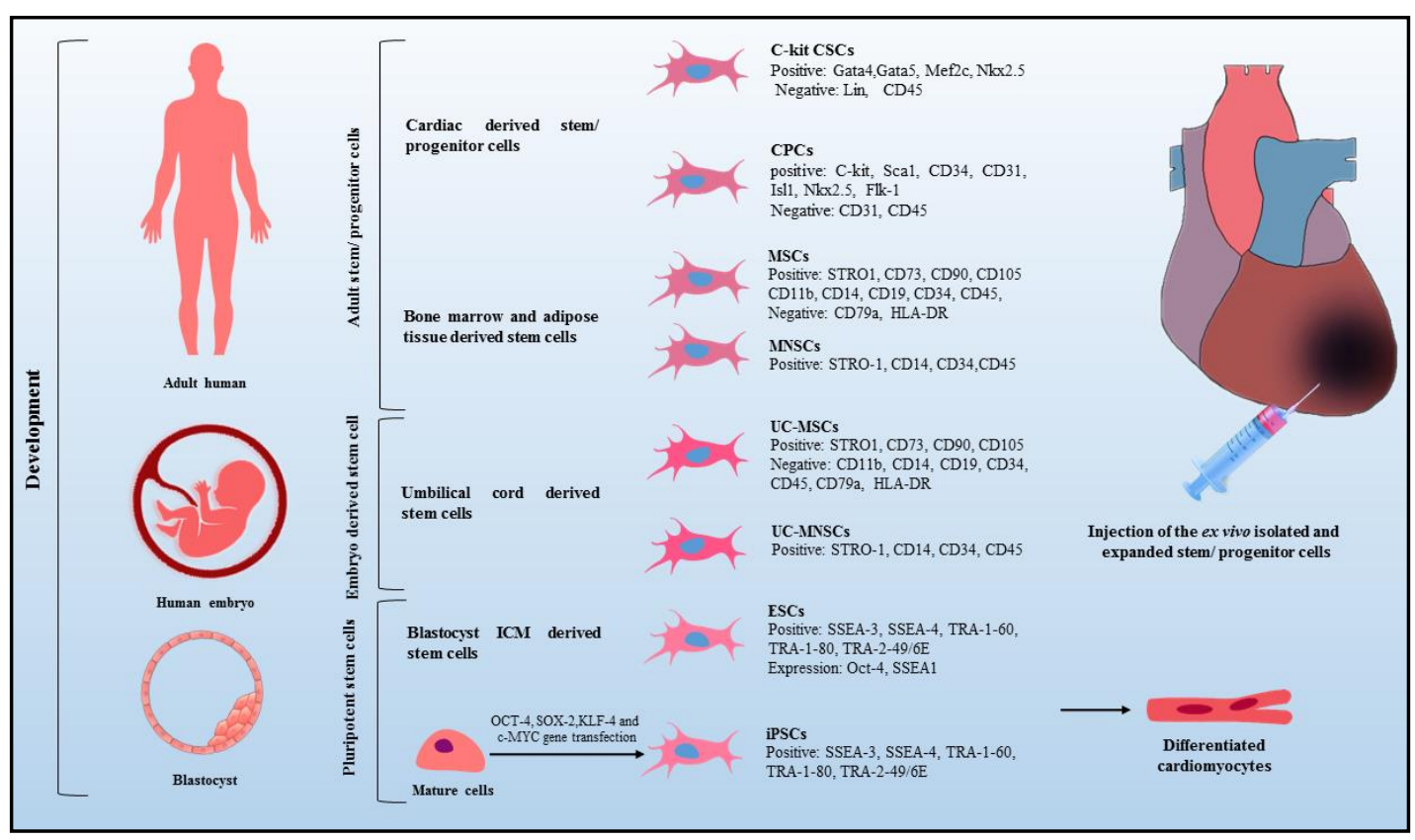

Fig. 1. Different sources and characteristics of the human pluripotent and adult stem cells for AMI cell therapy. Ex vivo differentiated cardiomyocytes from human PSCs for regenerating infarcted myocardium have shown. ESCs and iPSCs are the two main types of PSCs. Human ESCs directly isolate from blastocyst ICM, and human iPSCs may be directly generated from matured somatic cells through transfection of ESCs specific transcription factors. Human embryo umbilical cord is the primary source for obtaining UCMSCs and UC-MNSCs. In adults, MSCs and MNSCs can be isolated from bone marrow and adipose tissue as enrichment niches. Also, C-kit ${ }^{+}$CSCs and CPCs can be directly harvested from human myocardium. The cells can be characterized by the positive or negative expression of several markers and transcription factors. Abbreviations: CPCs: cardiosphere-derived stem cells, CSCs: cardiac stem cells, ICM: inner cell mass, ESCs: embryonic stem cells, iPSCs: induced pluripotent stem cells, MNSCs: mononuclear stem cells, MSCs: mesenchymal stem cells, UC-MNSCs: umbilical cord-derived mononuclear stem cells, and UC-MSCs: umbilical cord-derived mesenchymal stem cells.

and homeobox protein Nanog [17]. Human ESCs are further characterized by the positive expression of stage-specific embryonic antigens 3/4 (SSEA3/4), tumor resistance antigen 1-60 (TRA1-60), and tumor resistance antigen 1-80 (TRA1-80) markers [18] (Fig. 1). The ESCs potential for generating functional CMCs in an in vitro condition has been reported by Boheler, et al. (2002) for the first time [19]. This ESCs cardiomyogenic potential can be controlled by several growth factors, including vascular endothelial growth factor (VEGF), bone morphogenetic protein (BMP), and fibroblast growth factor-2 (FGF-2) [19]. It seems that these growth factors induce cardiomyogenic differentiation of the ESCs through activating several well-known downstream pathways such as phosphoinositide 3-kinase (PI3K) class IA, protein kinase C (PKC), and Wnt/ $\beta$-catenin signaling [20].

Induced pluripotent stem cells (iPSCs) are another type of the PSCs that can be derived from the mature somatic cells through transfection of the ESC-specific transcription factors, including OCT-4, SOX-2, kruppel-like factor-4 (KLF-4), and c-MYC [21]. Human iPSCs are characterized by the expression of the same markers specific to human ESCs, including stagespecific embryonic antigen-3 (SSEA-3), stage-specific embryonic antigen-4 (SSEA-4), TRA-160, TRA-1-80, and tumor resistance antigen-2-49/6E (TRA-2-49/6E) (Fig. 1). Several in vitro and in vivo studies have shown that the iPSCs are able to differentiate onto the functional CMCs and VECs. Besides, human iPSC-derived CMCs were observed to create a functional 3D cardiac micro-tissue [22]. Although direct implantation of the undifferentiated ESCs and iPSCs can effectively regenerate the injured tissues, teratogenicity is still one of the main 


\section{Cellular Physiology Cell Physiol Biochem 2019;53:887-909

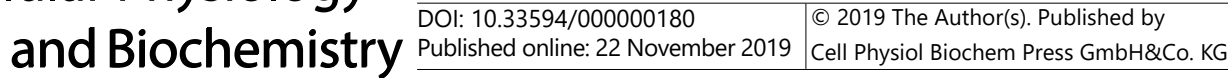 \\ Khodayari et al.: AMI Microenvironment: SCs Death \& Regeneration}

limitations against the clinical application of these cells $[16,23]$. The administration of the ex vivo PSC-derived CMCs appears to be a safe strategy to face such challenges.

\section{Adult stem/progenitor cells}

The adult SPCs are known as populations of animal cells with self-renewal and multipotent differentiation abilities. Presence of SPCs in the adult animal tissues implies to the regenerative potential of their organs throughout the lifespan. Mesenchymal stem cells (MSCs), bone marrow-derived mononuclear cells (BM-MNCs), and cardiac stem/progenitor cells (CSPCs) have been already studied for improving the heart injuries in patients with AMI [16] (Fig. 1).

MSCs and BM-MNCs are the most exploited SCs during clinical trials on heart regeneration. Human MSCs are isolated from different ontogenic sources including the bone marrow, the blood, the adipose tissue, and the umbilical cord. Additionally, MSCs and BMMNCs constitute a large number of $\mathrm{CD}_{34}^{+}, \mathrm{CD} 146^{+}$, and CD133 population of the human bone marrow cells [16] (Fig. 1).

Despite that the MSCs can be derived from different niches and are positively characterized by the expression of same markers such as CD70, CD90, and CD105 as well as negative expression of CD34 [24]. The MSCs show different gene expression patterns and regenerative potentials in the experimental studies [25]. The fate of MSCs are controlled directly through interaction with several growth factors, cytokines, and chemokines into the microenvironment of injured tissues. In this regard, VEGF, stromal cell-derived factor-1 (SDF1), basic fibroblast growth factor (b-FGF), and C-X-C chemokine receptor type 4 (CXCR4), as well as their downstream signaling pathways, have been demonstrated to actively stimulate the survival, proliferation, and differentiation of human MSCs [26]. The paracrine/autocrine activity of MSCs and BM-MNCs is an important mechanism for promoting cell survival, growth, and finally regeneration of an injured myocardium [27].

The CSPCs are populations of the cardiac-derived cells [28] that have potentials in generating the myocardium lineages like functional CMCs, VSMCs, and VECs under both in vitro and in vivo conditions [29]. The heart resident CSPCs have shown limited proliferative and paracrine/autocrine secretory responses around the infarcted myocardium zone following the heart injuries [30]. Expression of tyrosine-protein kinase Kit surface antigen (C-kit or CD117) is a major characteristic for the most types of the human and the mice CSPCs [30]. Furthermore, CSPCs are classified by expression of the cardiac-specific transcription factors such as GATA Binding Protein-4 (GATA-4), NK2 Homeobox 5 (Nkx-2.5), and myocyte enhancer factor-2 (MEF-2) [31] (Fig. 1). In terms of the heart regeneration, C-kit ${ }^{+}$cardiac stem cells (CSCs), Sca- $1^{+}$CSCs, cardiosphere-derived stem cells, and side population CSCs are the well-known SC populations within the mammalians heart [28, 29, 32]. The CSPCs cardiomyogenic differentiation can be regulated by several critical signaling pathways such as $\beta$-catenin and lipid raft/JNK/STAT3 [33].

\section{Acute myocardial infarction stem cell therapy}

During the myocardial infarction (MI), reduction of the ventricular wall thickness and induction of the heart failure resulting from the cardiomyocyte degeneration are inevitable processes. Heart SCs-based therapy introduces the most hopeful approach to protect and regenerate the missed myocardium areas [16]. Scientists believe that implanted SCs can regenerate the injured heart tissue through three main mechanisms including I. Secreting various kinds of the paracrine/autocrine factors into the injured microenvironment, II. Inducing endogenic CSPCs proliferation and differentiation, and III. Generating new CMCs and VECs into the failed areas. Thus far, several types of human cells including PSCs-derived CMCs [34, 35], CSPCs [2], MSCs, and BM-MNCs [36] have been examined in non-human primates and human patients with AMI during several phases of trials (Table 1). 


\section{Cellular Physiology Cell Physiol Biochem 2019;53:887-909 \begin{tabular}{ll|l} 
and Biochemistry $10.33594 / 000000180$ & Published online: 22 November 2019 & Cell Physiol Biochem Press GmbH\&Co. KG \\
\hline
\end{tabular} \\ Khodayari et al.: AMI Microenvironment: SCs Death \& Regeneration}

Table 1. Summary of some pre-clinical and clinical AMI stem cell therapy trials on non-human primate and human from 2010-2017 according to the cell type. Keys. AMI: acute myocardial infarction, CMCs: cardiomyocytes, ECs: endothelial cells, FHF: first heart field, H: human, IC: intracoronary, IM: intramyocardial, LV: left ventricular function, Ref: references, LVEF: left ventricular ejection fraction, NHP: nonhuman primate, SHF: second heart field, VSMCs: vascular smooth muscle cells, and WJMSC: Wharton's jellyderived mesenchymal stem cells

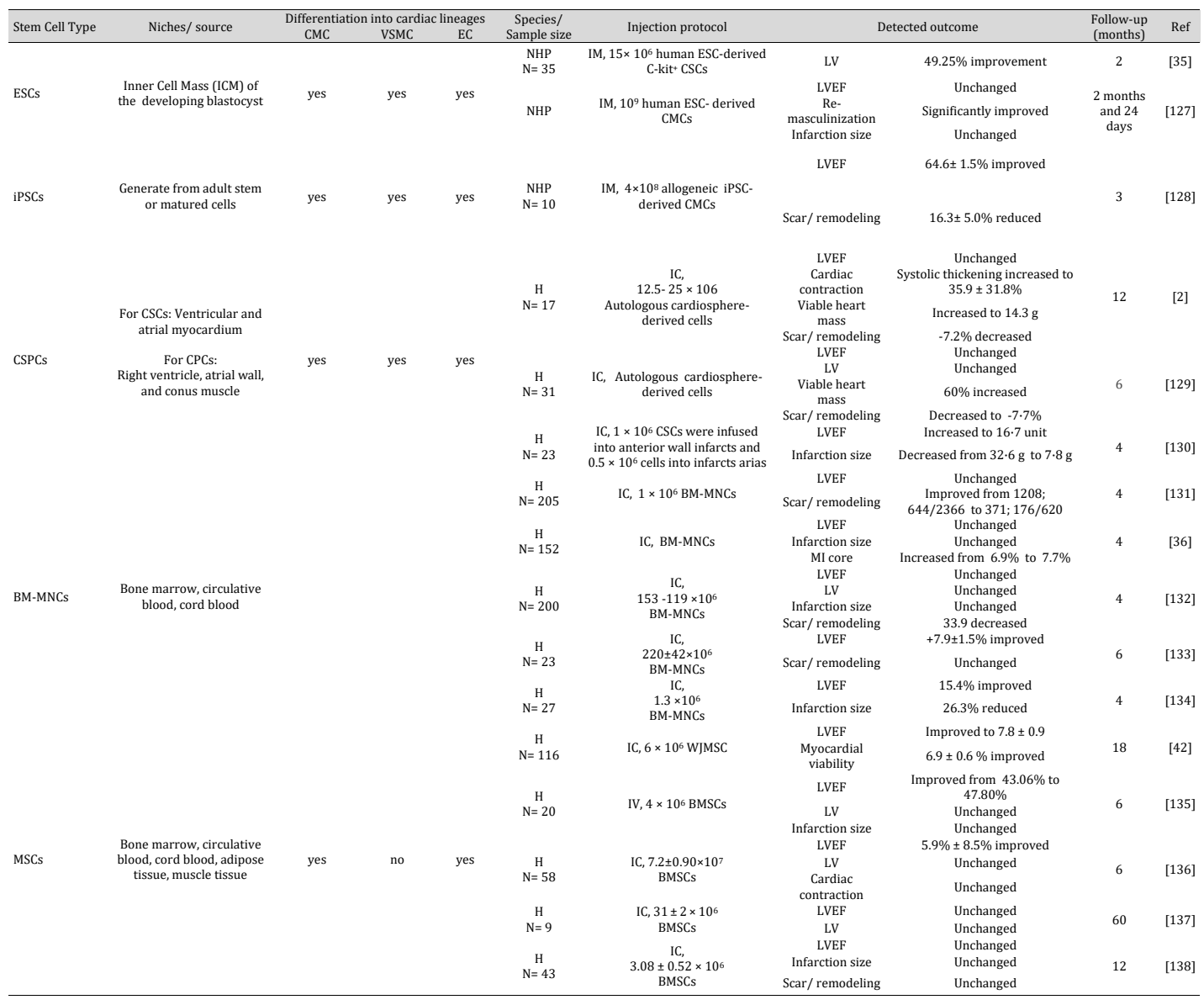

Differentiation of the human PSCs for generation of new heart lineage cells into the cardiac microenvironment has been clearly understood $[16,37]$. In the AMI animal models, implantation of the human undifferentiated PSCs into the injured myocardium has resulted in the improvement of heart functions through promoting a cardiomyogenic and angiogenic response [37]. Authors of an experimental study on the porcine model of ischemic myocardium have also demonstrated that direct injection of the human iPSCs could improve the animal's myocardial perfusion. They observed an increased response of myocytes generation, which was resulted from the differentiation of implanted iPSCs [38]. Conversely, a pre-clinical trial on non-human primate models of AMI indicated that the intramyocardial transplantation of human ESCs-derived CMCs did not significantly improve the animal's heart function [39]. Hence, it suggests that the application of undifferentiated PSCs have more efficiency to regenerate the injured myocardium in comparison with ex vivo generated and differentiated CMCs. Unfortunately, the high tendency of undifferentiated PSCs to teratogenic tumor formation $[23,40]$ and immunogenicity potential of these cells [41] are the main limitations for developing the undifferentiated ESCs- and iPSCs-based AMI regeneration in the clinical phases.

Safety and efficacy of the adult SPCs in AMI patients were studied in several clinical trials (Table 1). MSCs and BM-MNCs are the most trialed cells in these patients. Both of 


\section{Cellular Physiology Cell Physiol Biochem 2019;53:887-909 \\ \begin{tabular}{ll|l} 
and Biochemistry & $\begin{array}{l}\text { DOl: 10.33594/000000180 } \\
\text { Published online: 22 November } 2019\end{array}$ & $\begin{array}{l}\text { O } 2019 \text { The Author(s). Published by } \\
\text { Cell Physiol Biochem Press GmbH\&Co. KG }\end{array}$ \\
\cline { 2 - 3 } &
\end{tabular} \\ Khodayari et al.: AMI Microenvironment: SCs Death \& Regeneration}

these SCs could protect CMCs from death through secreting several types of paracrine/ autocrine factors into the AMI microenvironment $[16,27]$. These cells not only induce the revascularization of injured heart but also promote the formation of new cardiac muscle by promoting the endogenic CSPCs proliferation and differentiation [7]. The gelatinous mass within the umbilical cord, Wharton's jelly connective tissue, is known as a rich source of viable and fresh MSCs. LR Gao, et al. (2015) have tested the efficacy of Wharton's jellyderived MSCs through intracoronary infusion among AMI subjects. During the first four months, significant improvements were noticed in the patient's heart function indexes after treatment with MSCs. However, after an eighteen-month follow-up, a meaningful reduction was observed in the myocardial viability (PET) and perfusion within the infarcted territory (SPECT) following treatment with Wharton's jelly-derived MSCs [42]. Similar results were obtained by Huang, et al. (2015) through the intracoronary administration of BM-MNCs in a first ST-elevation myocardial infarction. They discerned a positive response in some patient's heart functions like LVEF [43]. In addition, using the hypoxia-preconditioned BM-MNCs in the AMI patients was noticed to significantly improve the efficacy of BM-MNCs-based heart regeneration [44] (Table 1).

Intramyocardial cell injection is another effective stem cell therapy method for the IHD cases [45]. Although different clinical observations have confirmed the efficacy and feasibility of this approach in non-AMI patients [46, 47], high invasiveness, limited numbers of useful stem cells, and low-cost efficiency can be considered as main limitations compared to the systemic delivery method $[47,48]$. Up to now, a few clinical trials have examined the benefits of intramyocardial stem cell transplantation for the AMI subjects. As the "first-inman study", Krause, et al. (2009) used intramyocardial delivery of MSCs in the AMI patients. Their results have clearly shown that this cell transplantation method could not provide a long term and stable improvement in the heart function. Nevertheless, their study confirmed the feasibility and safety of such a method of cell delivery in the AMI cases [49].

CSPCs have been highlighted as powerful cells with the capability of regenerating heart injuries in both pre-clinical and clinical trials (Table 1). In addition to creating several types of heart cells, transplanted CSPCs may promote survival and induce proliferation of the endogenic CSPCs through the expression of the numerous paracrine/autocrine factors into the AMI microenvironment, including tyrosine-protein kinase Met (c-Met), insulin-like growth factor-1 (IGF-1), and hepatocyte growth factor (HGF) [50]. Cardiosphere-derived progenitor cells (CPCs), as the most studied CSPCs, are colony-form heterogeneous cellular populations which can be directly harvested and then cultured from the myocardium tissue biopsies. In a clinical trial, after intracoronary injection of the autologous CPCs, regional function of infarcted segments was significantly improved, which was associated with reduced cardiac fibrosis, subsequently leading to the regeneration of a viable myocardium in patients with AMI. Moreover, Makkar, et al. (2012) have reported an unprecedented increase in the viable myocardium through the intracoronary infusion of the CPCs [2] (Table 1).

While many pre-clinical and some clinical trials prove positive effects of the heart SCsbased therapy, results from Lee SH, et al. (2016) meta-analysis (up to 2014) have revealed that utilizing SCs for the treatment of AMI may not be effective, except for short-term impact on recovery of the heart function [8]. In our opinion, inflammatory microenvironment in the acute phase of MI may exert an inhibitory role in the cell therapy. Therefore, we review the inflammatory microenvironment of AMI and the interaction of implanted SCs with this inflammatory condition.

\section{Inflammatory microenvironment of AMI}

Inflammation is known as an immunologic response, which plays a fundamental role in controlling of the tissue repair and degeneration. The AMI inflammatory microenvironment consists of various elements capable of inducing different responses on the infarcted area cells. The processes that promote such an inflammatory microenvironment include 


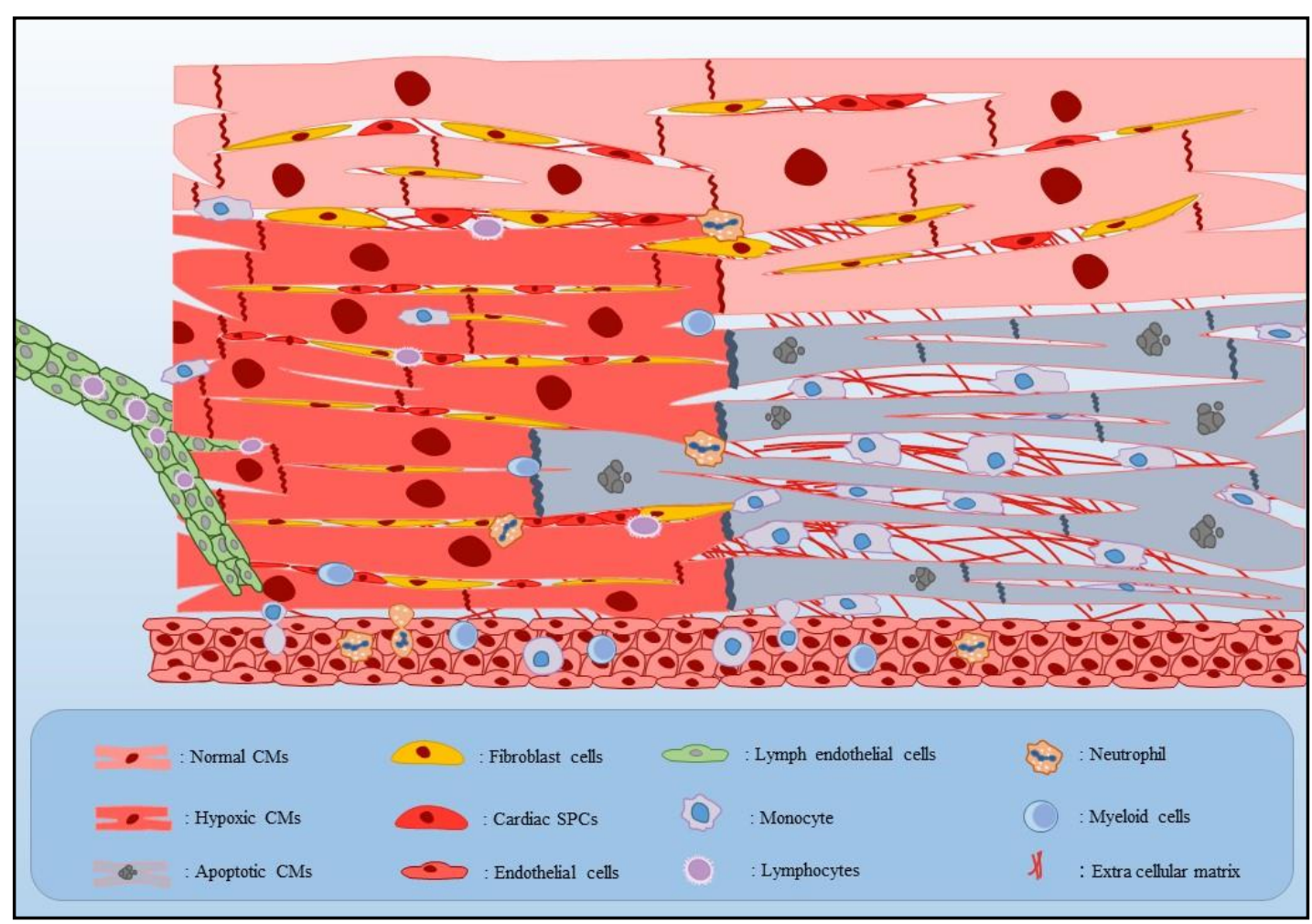

Fig. 2. Schematic representation of the AMI inflammatory microenvironment. Different populations of the fibroblasts, endogenic SPCs, and infiltrated immune cells into the separated parts of normal, hypoxic, and dead myocardium have been shown. Initially after hypoxia, injured CMs, fibroblasts, and endothelial cells actively secrete some of the major pro-inflammatory cytokines such as TNF- $\alpha$, IL- $1 \beta$, and also IL- 6 into the hypoxic areas. In addition, endogenous SPCs proliferation would be amplified in response to the hypoxia. Next, expression of some important integral membrane proteins including CXC and CC chemokines as well as up-regulation of adhesion molecules on the endothelial cells cause infiltration of inflammatory leucocytes including monocytes, neutrophils, and myeloid cells from the vessels and lymphocytes from the lymph into the infarcted areas. Afterwards, in addition to facilitating the healing process of an injured heart through removing the debris using phagocytosis and secreting some growth factors, recruited immune cells create a stress full inflammatory condition into the infarcted heart tissue via secreting pro-inflammatory cytokines. Abbreviations: CMs: cardiomyocytes, and SPCs: stem/progenitor cells.

I. Production of free radicals following the ischemia and/ or reperfusion, II. Infiltration of leukocytes into the infarcted tissue in response to the chemokines' expression, and III. Expression of pro-inflammatory cytokines by injured cells and infiltrated leucocytes [16] (Fig. 2). An appropriate recognition of this inflammatory and stressful condition can help to develop new practical approaches to regenerate the failed myocardium.

During the early phases of MI, oxidative stress resulted from the accumulation of the free radicals can cause myocardium degeneration through induction of lipid peroxidation, protein oxidizes, and DNA strand breaks, which it ultimately promotes the cellular death process $[51,52]$. In our opinion, inflammatory microenvironment in the acute phase of MI may exert an inhibitory role in the cell therapy. Therefore, we review the inflammatory microenvironment of AMI and the interaction of implanted SCs with this inflammatory condition.

It has been observed that the oxidative stress plays a primary role for generating free radicals in the cytoplasm of myocardium cells through promoting some mitochondrial pathways. In this regard, reactive oxygen species (ROS) and reactive nitrogen species (RNS) have been introduced as the main free radicals [51-53]. The production of these free radicals not only leads to apoptosis but also indorses chemotactic migration of inflammatory 


\section{Cellular Physiology Cell Physiol Biochem 2019;53:887-909

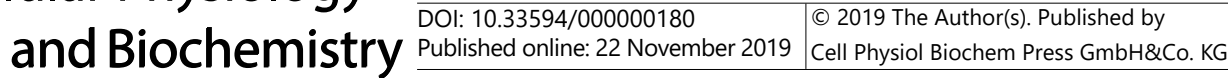 \\ Khodayari et al.: AMI Microenvironment: SCs Death \& Regeneration}

cells into the injured tissue microenvironment [53]. The chemotactic response of these leucocytes toward the infarct myocardium can be started by expression of some chemokines and cytokines factors, following by the synthesis of adhesion molecule on the endothelial cells surface, and then upregulated expression of leukocytes integrin [51]. Also, ROS elevate innate immune system responses immediately after MI via activation of alarmins or danger-associated molecular patterns (DAMPs), as structurally diverse intracellular signals, which can increase the stress and the inflammatory responses [54, 55]. Another member of alarmins, high mobility group protein B1 (HMGB1) plays an initiative role in activating toll-like receptors (TLRs) and developing inflammation response in the infarcted regions $[56,57]$. Moreover, formation of low-molecular weight hyaluronan and fibronectin into the degenerate myocardium extracellular matrix may promote the TLRs and other important pro-inflammatory signaling initiators [51,57]. Expression of some main integral membrane proteins including CXC and CC chemokinesis is well known as the main reason underlying the recruitment of inflammatory leukocytes into the AMI microenvironment beside the adhesion molecules [16, 58]. (Fig. 2).

Ly- $6 \mathrm{C}^{\text {high }}$ monocytes are the first stimulated immune cells in response to some CC chemokines expressions like CCL2. These monocytes can facilitate the heart healing process through phagocytosis and secreting proteolytic enzymes. Long-term activity of the Ly- $6 \mathrm{C}^{\text {high }}$ monocytes can be a destructive element in the AMI pathogenesis [59, 60]. Furthermore, triggering the synthesis of extracellular matrix and fibrosis are the main impacts of Ly- $6 \mathrm{C}^{\text {high }}$ monocytes activity into the infarcted microenvironment [61]. In the healing heart, switching the expression of CCL2 to the CX3CL1 as well as differentiation of the Ly- $6 \mathrm{C}^{\text {high }}$ monocytes can contribute to recruitment and increase of Ly- $6 C^{\text {low }}$ monocytes $[59,60,62]$. The Ly- $6 C^{\text {low }}$ monocytes actively support angiogenesis and extracellular matrix synthesis by secreting VEGF and transforming growth factor- $\beta$ (TGF- $\beta$ ) [59]. Through the AMI pathogenesis, CD- $4^{+}$ $\mathrm{T}$ lymphocytes expose a positive feedback on increasing the inflammation in a post-infarcted heart. Deficiency of the CD- $4^{+} \mathrm{T}$ cell may disturb the transition of Ly- $6 \mathrm{C}^{\text {high }}$ monocyte to Ly-6 C low [63]. Myeloid cells, as another type of leucocytes, return into draining lymph nodes shortly after ischemic injury [61]. Myeloid cells have a particular function in the infarcted myocardium pathogenesis through secretion of several pro-apoptotic factors and cardiac collagen matrix proteolysis [10] (Fig. 2).

The complex pro- and anti-inflammatory cytokine network is an undeniable part of the stressful AMI microenvironment. Pleiotropic properties of the pro-inflammatory cytokines act as the core factors in developing the myocardium degeneration and the healing process [64]. In this respect, TNF- $\alpha$, interleukin-1 (IL-1) family, and also IL-6 family are the most common inflammatory cytokines in this complex network $[51,64]$.

In a post-infarcted myocardium, activation of hypoxia-inducible factor- $1 \alpha$ (HIF- $1 \alpha$ ) from the damaged cells directly stimulates secretion of the TNF- $\alpha$ in a post-infarcted heart [16, 65] (Fig. 3). According to the experimental models, activation of the TNF-Rs into the infarcted zone ultimately leads to the matrix metalloproteinase activity and extracellular matrix degradation $[51,65,66]$. Besides, TNF-Rs stimulation can induce activation of cellular death inducer signaling pathways in the CMCs and endothelial cells [67]. Study on the TNFR1/TNFR2-genetically knockout mice has shown that CMCs apoptosis did not appear on the TNFR1/TNFR2-knockout mice myocardium after an acute ischemic injury [51]. This study not only realized the TNF- $\alpha$ / TNF-Rs as the major cell death inducer in the path of AMI pathogenesis but also suggests those as a powerful target for the future heart regeneration goals.

Irrespective of the TNF- $\alpha$, secretion of IL-1 family, as another important pro-inflammatory cytokine, can mediate activation and recruitment of the inflammatory leukocyte $[51,68]$. IL$1 \alpha$, IL-1 $\beta$, and IL-1 receptor antagonist (IL-1ra) are the main members of the IL-1 family [68]. It seems that in an AMI microenvironment, the expression pattern of chemokines, growth factors, and adhesion molecules might be controlled by the IL- $1 \alpha$ and the IL- $1 \beta$ related processes [69]. Despite the recognition of the IL-1 $\beta$ as one of the primary death ligands and apoptotic inducer, some believe that the IL-1 $\beta$ might be free of any significant detrimental 


\section{Cellular Physiology Cell Physiol Biochem 2019;53:887-909

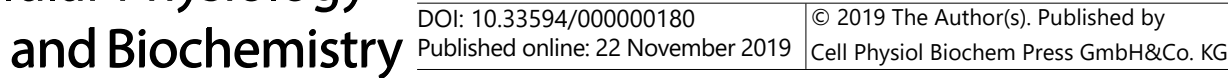 \\ Khodayari et al.: AMI Microenvironment: SCs Death \& Regeneration}

outcomes on the injured CMCs [69]. As the natural inhibitor of the IL-1 family, the IL-1ra can provide a protective and anti-apoptotic role for CMCs by inhibiting the IL- $1 \alpha$ and the IL- $1 \beta$ expression in the infarcted cells $[68,70]$.

Notwithstanding, the fact that the level of IL-6 family members increase immediately after MI by the infiltrated leucocytes and the injured CMCs, function of the IL- 6 family in an infarct heart is still to be determined [51, 71]. IL-6, IL-11, leukemia inhibitory factor (LIF), oncostatin M (OSM), ciliary neurotrophic factor (CNTF), cardiotrophin-1 (CT-1), cardiotrophin-like cytokine (CLC), and neurotrophin-1/B-cell stimulating factor-3 (NNT-1/ BSF-3) are members of the IL-6-type family cytokines which have both pro-inflammatory and anti-inflammatory implications. Increasing the cell apoptosis together with inducing the cell proliferation, differentiation, and survival are the IL-6-type cytokines contradictory attributed functions [72].

The cellular mechanisms and signaling pathways regulated by pro-inflammatory cytokine network into the AMI microenvironment are known as the most disruptive elements to the biological action of endogenous and exogenous SCs. All of these mechanisms from the beginning of hypoxia to the loss of CMCs are dynamic and aggressive processes, which can affect the implanted cells efficiency to regenerate the injured myocardium in the acute phases of AMI.

\section{Interaction of the stem cells with inflammatory myocardial microenvironment}

It is observed that about $90 \%$ of all types of transplanted cells die within 4 days following transplantation into a post-infarcted heart $[73,74]$. Thus, the interaction of the infarcted heart microenvironment mediators with the transplanted cells is a determinative factor in the outcome of cardiac cell therapy. It seems that multiple mechanisms such as I. Injured heart tissue inflammatory response, II. Decreasing the oxygen (Hypoxia) and substrates delivery, III. Loss of the cell-cell contact, and IV. Several cytotoxic and/or proapoptotic factors contribute to induce the cellular death on the implanted cells in an AMI inflammatory condition. Improving the implanted cell survival after the administration is a crucial matter to enhance the efficacy of stem cell therap.

It has been clearly observed that the survival of bone marrow-derived MSCs (BMSCs) within the ischemic region significantly decreased early after transplantation [75]. Interaction of these SCs with the secreted TNF- $\alpha$, IL-1 members, IL-2, IL-6, interferon (IFN)- $\gamma$, and their related signaling pathways plays a vital role in the implanted cells death [76]. Additionally, some of these cytokine receptors and their related ligands including TNF-R1, IL-1R (receptor of the IL-1), apoptosis antigen 1 (APO-1 also known FAS), and TNF-related apoptosis-inducing ligand (TRAIL-R), as the main members of death ligands, can induce apoptotic cell death and tissue necrosis through activating nuclear factor- kappa B (NF- $\kappa B$ ) cascade $[76,77]$. In infarcted cells, the NF- $\mathrm{BB}$ is the first responder to the harmful cellular stimuli such as cytokines as well as free radicals. Generally, the NF- $\mathrm{BB}$ protein complex controls the cytotoxic cytokine expression and also negatively affects the cell survival in the myocardium. Activation of this factor through death ligands stimulation can directly develop apoptosis mechanisms into the SCs via overexpression of pro-apoptotic Bcl-2-associated X protein (Bax) gene $[51,78]$. Moreover, these death ligands could mediate autophagy cascade during the cardiac injury through inhibiting mammalian target of rapamycin (mTOR) and Ras pathways [51] (Fig. 3). In MSCs, TNF- $\alpha$ and IFN- $\gamma$ networks can synergistically enhance the autophagy and apoptosis by stimulating ROS/ mitogen-activated protein kinase 1/3 (ERK) pathway, inducing Bcl-2-homology (BH)-3 domain only protein (Beclin-1) gene expression, and inhibiting anti-apoptotic B-cell lymphoma 2 (Bcl-2) expression (Fig. 3).

Within such a complex environment, hypoxia and inflammation can induce cell death and local cellular degeneration on the endogenous and the injected SCs. By promoting several mitochondrial pore formation proteins, hypoxia-mediated oxidative stress makes an essential interposition in the SCs apoptosis induction. Decreasing the expression of anti- 


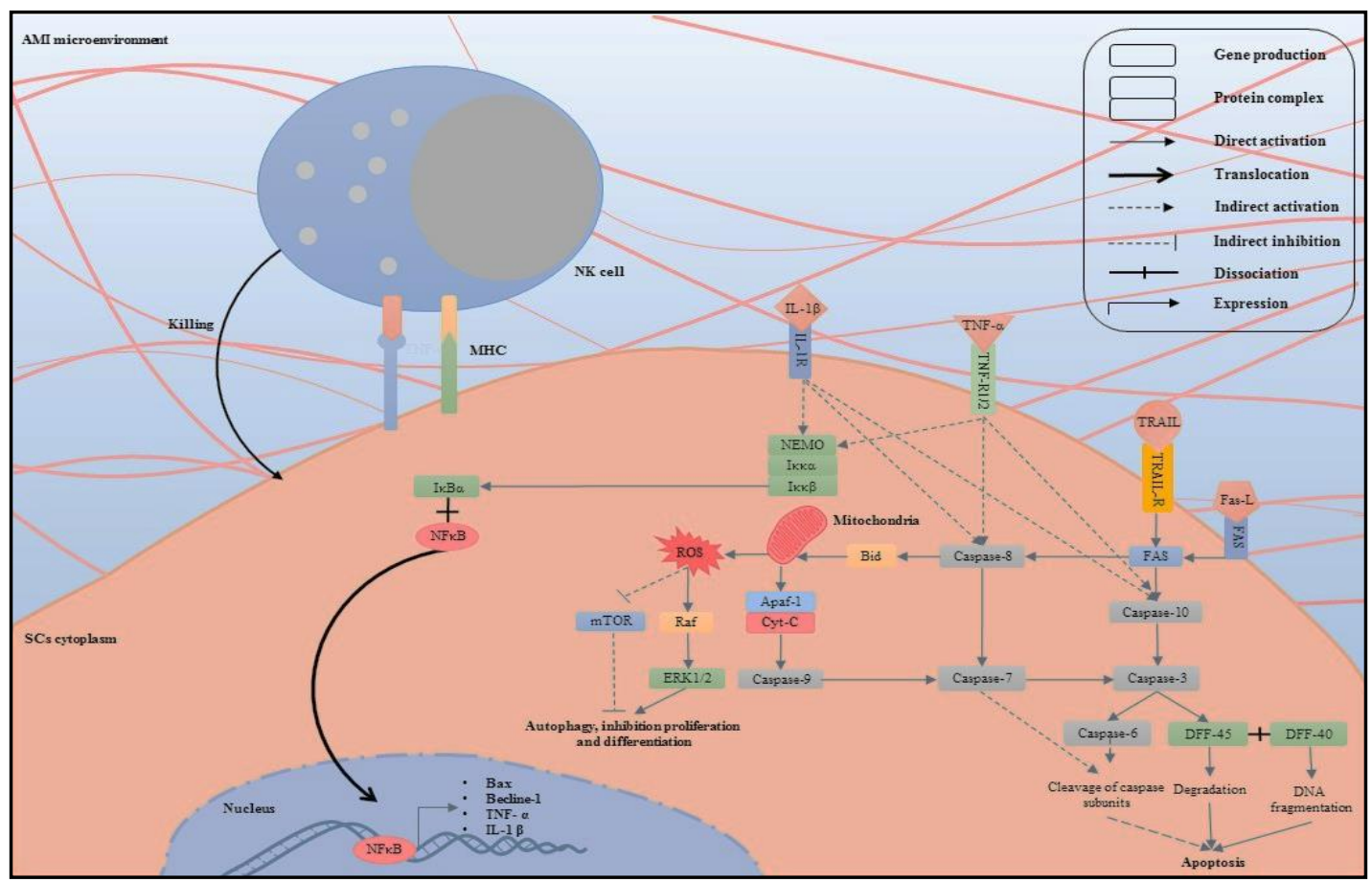

Fig. 3. The SCs interaction with AMI inflammatory microenvironment. TNF-R1/2, IL-1R, Fas, and TRAIL-R as the main death ligands have a central role in inducing SCs death into the inflammatory microenvironment of AMI. During the maintained process, activation of the Fas and the TRAIL-R ligands by their stimulators can directly promote caspase- 8 and -10 related apoptosis cascades. In addition, caspase- 8 and -10 related cascades indirectly can promote through TNF- $\alpha$ and IL-1 $\beta$ secretion. Following, apoptosis cell death occurs within activation of caspase-7 and then caspase-3. Moreover, activation of Caspase- 3 through caspase- 6 stimulation and dissociation of DFF-40 and DFF-45 leads to apoptosis in the implanted cells. On the other hand, activation of the mitochondrial related pathways can effectively enhance SCs death. Formation of apoptosome complex (Cyt-C + Apaf-1) through caspase-9 activation, RoS production via activation of MAPK (ERK 1/2) signaling pathway, and inhibiting the mTOR cause to SCs apoptosis, autophagy as well as inhibition of SCs proliferation and differentiation. Furthermore, NF- $\kappa B$ stimulation and translocation into the nucleus by TNF-R1/2 and IL-1R has a central roles in overexpression of pro-apoptotic and also proinflammatory cytokine genes. Expression of some MHCs on the implanted SCs into the AMI inflammatory microenvironment via recruitment of NK cell leads to the rejection of the SCs. Abbreviations: AMI: acute myocardial infarction, Apaf-1: apoptotic protease activating factor 1, Bax: Bcl-2-associated X protein, Becline-1: coiled-coil myosin-like BCL2-interacting protein, Bid: BH3-interacting domain death agonist, Cyt-C: cytochrome -C, DFF: DNA fragmentation factor, ERK: extracellular signal-regulated kinases, Fas: apoptosis antigen 1 (APO-1 or APT), Fas-L: Fas ligand, IL-1R: interleukin-1 receptor, IL-1ß: interleukin-1 $\beta$, ІкB $\alpha$ : nuclear factor of kappa light polypeptide gene enhancer in B-cells inhibitor- $\alpha$, Iкк: inhibitory Kappa Kinase $\alpha$, MAPK: mitogen-activated protein kinase, MHC: major histocompatibility complex, mTOR: mechanistic target of rapamycin, NEMO: NF-kappa-B essential modulator, NFкB: nuclear factor kappa-lightchain-enhancer of activated B cells , NK cells: natural killer cells, Raf: serine/threonine-protein kinase, ROS: reactive oxygen spices, SCs: stem cells, TNF-R: tumor necrosis factor receptor, TNF- $\alpha$ : tumor necrosis factor$\alpha$, TRAIL: TNF-related apoptosis-inducing ligand, and TRAIL-R: TNF-related apoptosis-inducing receptor., and Becline-1: coiled-coil myosin-like BCL2-interacting protein

apoptotic proteins like $\mathrm{Bcl}-2$ and increasing the pro-apoptotic proteins expression such as Bax, Bcl-2 associated death promoter (Bad), and glycogen synthase kinase $3 \beta$ (GSK-3 $\beta$ ) are the main targets of hypoxia-mediated oxidative stress [51, 79]. Furthermore, autophagy cell death can be induced over ROS-mediated endoplasmic reticulum (ER) specific protein misfolding, and also stimulation of Ras and ERK1/2 signaling pathways [80, 81] (Fig. 3). Likewise, the inhibitory effects of TNF- $\alpha$ on the secretion of stem cell factor (SCF), as one of 


\section{Cellular Physiology Cell Physiol Biochem 2019;53:887-909 \\ \begin{tabular}{ll|l} 
and Biochemistry & $\begin{array}{l}\text { DOl: 10.33594/000000180 } \\
\text { Published online: 22 November } 2019\end{array}$ & $\begin{array}{l}\text { O } 2019 \text { The Author(s). Published by } \\
\text { Cell Physiol Biochem Press GmbH\&Co. KG }\end{array}$ \\
\cline { 2 - 3 } &
\end{tabular} \\ Khodayari et al.: AMI Microenvironment: SCs Death \& Regeneration}

the important cardiogenic elements, have been already shown [82, 83]. Moreover, according to an experimental study, TNF-R inhibits of the growth factor and cytokine production of SCs. Markel, et al. (2007) observed that TNF-R1-ablated BMSCs have had higher basal levels of IL-6, VEGF, and IGF-1 compared with unstimulated wild-type SCs, although no significant alterations were observed in the secretomes of TNF-R2-ablated BMSCs [84]. Thus, taking advantage of approaches based on the AMI inflammatory microenvironment inhibition can be an effective way to decrease these detrimental effects. Relying on the above-mentioned hypotheses and through transplantation of skeletal myoblasts (SkMs) into the MI regions, a significant CMCs protection and heart regeneration was recorded via expression of IL-1ra (major IL-1 endogenous inhibitor) and inhibition of pro-inflammatory cytokines such as TNF- $\alpha$ and IL-1 $\beta$ into the rodent's infarcted myocardium [85]. However, the SkMs utilization, as a disparate cellular population from the heart lineage cells, seems to case some of the malintegration related problems after transplantation into the injured myocardium.

The activity of natural killer (NK) cells resulted from the cytokines network could aggressively lyse the implanted SCs [86]. NK cells, a strong cytolysis immune cells, have a critical role in the process of implanted cells/tissues rejection [87]. It has been shown that some of the major histocompatibility antigens (MHC) especially class I and II are up-regulated in the implanted SCs and/or differentiated CMCs inside an inflammatory microenvironment, which actively causes rejection of transplanted cells through NK cells cytolysis response [88].

SCs differentiation onto the heart cells lineages as well as preserving survival are other notable challenges in the way of heart SCs-based therapy. In this context, the infarcted cardiac microenvironment had a disruptive effect on the SCs cardiomyogenic potential [89]. The hindered effects of AMI microenvironment on the human ESCs cardiac lineage differentiation have been carefully determined [86]. In addition, some studies have clearly proved that the TNF- $\alpha$ and its mediated signaling pathways inhibit the cardiomyogenic differentiation of the CSPCs and promote a neuroaderenergic-like fate. These observations showed the probable impact of both TNF-R1 and TNF-R2 on decreasing the CSPCs differentiation potentials and proliferation through stimulation of the NF- $\kappa B$ and mitogen-activated protein kinase (MAPK) pathways around the infarcted zone [14].

\section{Efficient approaches to overcome challenges}

The efficacy of the cell therapy is affected by multiple biological factors. Activation of complex inflammatory network early after heart injury, diffusion of the inflammatory leucocytes into the injured tissue, and also secretion of different pro-inflammatory cytokines aggressively induce a harmful condition for all types of the implanted cells (Fig. 3). Generation of such an unstable and progressive microenvironment can dramatically inhibit the survival, function, and differentiation of implanted SCs. In this regard, the authors suggest four different experimental approaches for improving the regenerative responses after the AMI SCs-based therapy, including I. Co-delivery of MSCs with the other useful SPCs, II. Using the SPCs-derived secretomes and/or exosomes, III. Using the preconditioned and modified SPCs, and IV. Using anti-inflammatory drugs before the cell therapy (Table 2).

Due to cytokine-induced stimulation and through the paracrine/autocrine activity, MSCs can effectively improve the heart regeneration by suppressing the inflammatory response. Generally, MSCs-derived paracrine/autocrine factors are grouped into three classes including a. Immune suppressive factors such as nitric oxide (NO), interlykin-10 (IL-10) [90], transforming growth factor- $\beta$ (TGF- $\beta$ ) [91], and chemokine ligand-2 (CCL-2) [92], b. Growth factors like epidermal growth factor (EGF), platelet-derived growth factor (PDGF), VEGF, and SDF-1 [93], and c. Surface markers such as Galectin [94], intercellular adhesion molecule-1 (ICAM-1), and vascular cell adhesion molecule-1 (VCAM-1) [95]. It has been observed that all of these MESs-secreted factors may actively improve SCs functions in the injured myocardium. 


\section{Cellular Physiology Cell Physiol Biochem 2019;53:887-909 \begin{tabular}{ll|l} 
and Biochemistry & DOl: 10.33594/000000180 & Published online: 22 November 2019 The Author(s). Published by \\
\cline { 2 - 3 } & Cell Physiol Biochem Press GmbH\&Co. KG
\end{tabular}}

Table 2. Main stem cell therapy studies showing more improvement in AMI due to MSCs co-injection, SCs exosomes/ secretomes synchronic administration, and preconditioned or gene modified SCs. Keys: ASCs: adipose tissue derived-stem cell, AT2R/p-ERK/eNOS/NO: angiotensin type 2 receptor / extracellularsignal-regulated kinase/ endothelial nitric oxide/ nitric oxide, Bax: Bcl-2-associated X protein, Bcl2: B-cell lymphoma 2, bEGF: human epidermal growth factor, CCL2: C-C motif chemokine ligand 2, CMs: cardiomyocytes, cTnI: although assays for cardiac troponin T, eNOS: endothelial Nitric Oxide, hEnMSCs: human endometrium mesenchymal stem cells, HIF-1 $\alpha$ : hypoxia-inducible factor- $1 \alpha$, hIPSCs: human inductive pluripotent stem cell, Hs-CRP: High-sensitivity CRP, hUC-MSCs: human umbilical cord-derived mesenchymal stem cells, ICAM-1: Intercellular Adhesion Molecule 1, IL-10: interloukin-10, IM injection: Intramyocardial injection, IV injection: Intravein injection, LV: left ventricle, LVEF: left ventricular injection fraction, NO: nitric oxide, PCNA: Proliferating cell nuclear antigen, PDGF: Platelet-derived growth factor, pGSK3 $\beta$ : phospho Glycogen synthase kinase $3 \beta$, PKCe: protein kinase $C \varepsilon$, PKG1: protein kinase G1, PTEN/ Akt: phosphatase and tensin homolog/ Protein kinase B, RhoA/ROCK/ERK: Ras homolog gene family, member A/ Rho-associated protein kinase/ extracellular signal-regulated kinases, rMSCs: rat mesenchymal stem cells, SDF/CXCR4: stem cell derived factor/ C-X-C chemokine receptor type 4, SDF-1: stem cell derived growth factor-1, SMA: smooth muscle actin, SOS-1: Son of sevenless homolog 1, TGF- $\beta$ : Tumor necrosis factor- $\beta$, TNF- $\alpha$ : Tumor necrosis factor- $\alpha$, VCAM-1: Vascular cell adhesion protein 1, VEGF: vascular endothelial growth factor, and vWF: von willebrand factor

\begin{tabular}{|c|c|c|c|c|c|c|}
\hline Stem cells and preparation & Stem cell niche & Protocol & Spices & Outcome & Discussion: mechanisms & Ref \\
\hline \multirow{4}{*}{ MSCs co-injection } & C-Kit ${ }^{+}$CSCs & $\begin{array}{l}\text { IV co-injection of the 1-2×106 EPCs } \\
\text { with BM-MSCs }\end{array}$ & Rat & $\begin{array}{l}\text {. Improved cardiac function } \\
\text { - Increased cMs formation and capiliary density } \\
\text {. Induced expression of angiogenic genes }\end{array}$ & Regulation of AMI inflammatory microenvironment through & [92] \\
\hline & $\begin{array}{l}\text { h-PPSCs derived } \\
\text { CMs }\end{array}$ & $\begin{array}{l}\text { IM co-injection of the } 10^{6} \mathrm{~h} \text {-IPSCS- } \\
\text { MCs with } 10^{6} \mathrm{hMSC}\end{array}$ & $\begin{array}{c}\text { Nude } \\
\text { hydrate }\end{array}$ & $\begin{array}{l}\text { IImproved cardiac function. } \\
\text {. Increased level expression of connexin-43, } \alpha-\text {-actinin and } \\
\text { myosin heavy chain }\end{array}$ & 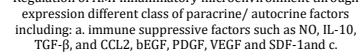 & [131] \\
\hline & EPCS & $\begin{array}{l}\text { IM co-injection of the } 5 \times 10^{5} \mathrm{MSCs} \\
\text { with } 5 \times 10^{5} \mathrm{EPCs}\end{array}$ & Rat & $\begin{array}{l}\text {.Improvede ejection fraction } \\
. \text { Improved arteriole density }\end{array}$ & $\begin{array}{l}\text { surface markers such as Galectin, intercellular ICAM-1, and } \\
\text { VCAM-1. }\end{array}$ & [132] \\
\hline & Autologous EPCs & $\begin{array}{l}\text { IV co-injection of the } 5 \times 10^{5} \text { EPCs } \\
\text { with } 5 \times 10^{5} \text { BMSCs }\end{array}$ & $\begin{array}{c}\text { Human } \\
(\mathrm{n}=11)\end{array}$ & $\begin{array}{l}\text { - Increased myocardial contractibility } \\
\text {. Decreased scar tissue }\end{array}$ & & [133] \\
\hline \multirow{7}{*}{ Using of exosomes or secretomes } & $\begin{array}{l}\text { Akt-modified hUC- } \\
\text { MSCs-derived } \\
\text { exosomes }\end{array}$ & $\begin{array}{l}\text { IV injection, various source exosomes } \\
\text { (400 } \mathrm{\mu g} \text { of protein) }\end{array}$ & Rat & $\begin{array}{l}\text { Improved the heart functions } \\
\text { - Increased endothelial cells level and blood vessel } \\
\text { formation } \\
\text { formon }\end{array}$ & $\begin{array}{l}\text { Enhance activation of PDGF signaling pathway into the AMI } \\
\text { microenvironment. }\end{array}$ & [134] \\
\hline & $\begin{array}{l}\text { Cardiosphere- } \\
\text { derived stem cells- } \\
\text { derived exosomes }\end{array}$ & $\begin{array}{l}\text { IM injection, CDCs exosomes (or } \\
\text { vehicle) }\end{array}$ & Porcine & $\begin{array}{l}\text { Improved LVEF } \\
\text { - Decreased infarcted size, scar size, LV collagen content } \\
\text { and cardiomycocyte hypertrophy cont } \\
\text { Increased vessel density in the histological observation }\end{array}$ & $\begin{array}{l}\text { Enhance activation of anti-apoptotic and heart regenerative } \\
\text { signaling factor. }\end{array}$ & [135] \\
\hline & $\begin{array}{l}\text { Macrophage- } \\
\text { derived mir-155- } \\
\text { containing } \\
\text { exosomes }\end{array}$ & $\begin{array}{l}\text { IV injection, exosomes derived from } \\
\text { Angll-stimulated WT macrophages } \\
\text { (100 or } 200 \mathrm{mg})\end{array}$ & $\begin{array}{c}\text { mir-155-\% } \\
\text { mice and } \\
\text { littermate } \\
\text { WT mice } \\
\text { in } \\
\text { C57BL/6 }\end{array}$ & $\begin{array}{l}\text { - Exhibition of fibroblast proliferation and collagen } \\
\text { production } \\
\text { - Reduced cardiac inflammmation response into the AMI } \\
\text { microenvironment }\end{array}$ & $\begin{array}{l}\text { Inhibit cardiac fibroblast proliferation by inhibition SOS-1 } \\
\text { expression and also inhibitited cardiac inflammation by } \\
\text { decreasing Suppressor of Cytokine Signaling } 1 \text { expression }\end{array}$ & [136] \\
\hline & $\begin{array}{l}\text { hEnMSCs- derived } \\
\text { exosomes }\end{array}$ & $\begin{array}{l}\text { IM injection of } 1 \times 10^{6} \text { exosome (mir- } \\
\text { 21-containing exosomes) secreting } \\
\text { hEnMSCs }\end{array}$ & Rat & $\begin{array}{l}\text { - Increased cardiomyocytes protection and survival } \\
\text { Increased neovascularization and masculinization }\end{array}$ & $\begin{array}{l}\text { Enhance cell survival through activation of PTEN/Akt } \\
\text { pathway into the AMI microenvironment }\end{array}$ & {$[137]$} \\
\hline & $\begin{array}{l}\text { Sca-1+ CSCs } \\
\text { secretome }\end{array}$ & $\begin{array}{l}\text { Direct interaction and culture of } \\
\text { hypoxic cardiomyocytes with the Sca- } \\
1+\text { CSCs secretomes }\end{array}$ & rCMs & - Protection of CMs from hypoxic injury & $\begin{array}{l}\text { Enhance activation of MCP-1-dependent mechanism into } \\
\text { the AMI microenvironment }\end{array}$ & [97] \\
\hline & $\begin{array}{l}\text { Dendritic cells - } \\
\text { derived exosomes }\end{array}$ & $\begin{array}{l}\text { IV injection, exosomes derived from } \\
\text { dendritic cells }\end{array}$ & Mice & $\begin{array}{l}\text {. Improved heart functions } \\
\text {. Increased myocardial inflammation } \\
\text {. Reduced infarct size }\end{array}$ & $\begin{array}{l}\text { Enhance activation of } \mathrm{CD} 4+\mathrm{T} \text { lymphocytes and its related } \\
\text { signaling into the AMI microenvironment }\end{array}$ & [138] \\
\hline & $\begin{array}{c}\text { rMSCs-derived } \\
\text { exosomes }\end{array}$ & $\begin{array}{l}\text { IM injection, exosomes derived from } \\
\text { rMSCS. }\end{array}$ & Rat & $\begin{array}{l}\text { - Preserved cardiac systolic and diastolic performance } \\
\text {. Increased neovascularization } \\
\text { - Restrain inflammation response into the AMI } \\
\text { microenvironment } \\
\text {. mproved LVEF }\end{array}$ & $\begin{array}{l}\text { Enhance activation of angiogenic and anti-inflammation } \\
\text { mechanisms into the AMI microenvironment }\end{array}$ & [95] \\
\hline \multirow{5}{*}{ Using of preconditioned SCs } & $\begin{array}{c}\text { Hypoxic } \\
\text { preconditioning }\end{array}$ & $\begin{array}{l}\text { HP protocol: } 0.5 \% 02 \text { for } 24 \mathrm{~h} \\
\text { Im injection, } 1 \times 10^{7} \mathrm{NHP}-\mathrm{MSCS}\end{array}$ & NHP & $\begin{array}{l}\text {. Improved LVEF } \\
\text {. Decreased infarct size } \\
\text {. Increased myocardium thickness }\end{array}$ & $\begin{array}{l}\text { Hypoxia preconditioning increase the expression of several } \\
\text { prosurvival/proangiogenic factors into the stem cells. }\end{array}$ & [101] \\
\hline & Diazoxide & $\begin{array}{l}\text { IM injection. } 10^{6} \mathrm{EPCS} \text { cultured with } \\
200 \mu \mathrm{M} \mathrm{DZ}\end{array}$ & Rat & $\begin{array}{l}\cdot \text { Improved cardiac function } \\
\text {. Reduction in infacts size } \\
\text {. Increased cell proliferation and angiogenesis }\end{array}$ & 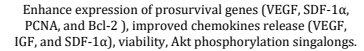 & [139] \\
\hline & Angiotensin II & $\begin{array}{l}\text { IM injection, } 3 \times 10^{6} \text { BMMNCs } \\
\text { cultured with } 100 \mathrm{nM} \text { AngIII }\end{array}$ & Rat & $\begin{array}{l}\text { - Improved vessel density in peri-infarct region and } \\
\text { attenuated infarct size }\end{array}$ & $\begin{array}{l}\text { Enhance activation of AT2R/pERK/ / NOS /NO, VEGF and } \\
\text { anti-apoptotic signaling into the stem cells. }\end{array}$ & [140] \\
\hline & $\begin{array}{l}\text { phosphodiesterase- } \\
5 \text { inhibition }\end{array}$ & $\begin{array}{l}\text { IM injection, } 5 \times 10^{5} \text { PED- } 5 \\
\text { suppressed ASCS }\end{array}$ & Mice & $\begin{array}{l}\text {-Reduced cardiac fibrosis, } \\
\text {. Increased vascular density } \\
\text {. Decreased resident myocyte apoptosis }\end{array}$ & $\begin{array}{l}\text { Enhance activation of VEGF, b-FGF, and Angiopoietin-1 } \\
\text { signaling pathway }\end{array}$ & [141] \\
\hline & $\begin{array}{c}\text { Hypoxic } \\
\text { preconditioning }\end{array}$ & $\begin{array}{l}\text { HP protocol: } 0.1 \% 02 \text { for } 6 \mathrm{~h} \text {. } \\
\text { IV injection, } 1 \times 10^{6} \mathrm{HP}-\mathrm{CPCS}\end{array}$ & Mice & $\begin{array}{l}\text { Improved heart function } \\
\text {. Increased infarct size }\end{array}$ & Enhance activation of SDF/CXCR4 signaling pathway. & [142] \\
\hline \multirow{7}{*}{ Using of genetically modified SCs } & $\mathrm{IL}-10$ & $\begin{array}{l}\text { IM injection, } 210^{6} \mathrm{IL}-10-\mathrm{MSCS} \\
\text { modified cells }\end{array}$ & Rat & $\begin{array}{l}\text { - Reduced myocardial infarct size, cardiac impairment, } \\
\text { and cell apoptosis }\end{array}$ & $\begin{array}{l}\text { Increase expression of Lil-10 into the AMII } \\
\text { microenvironment and suppress pro-inflammatory } \\
\text { cytokines expression and signaling. }\end{array}$ & [143] \\
\hline & enOS & $\begin{array}{l}\text { IM injection, } 2 \times 10^{6} \text { eNOS-BMMSCs } \\
\text { modified cells }\end{array}$ & Rat & $\begin{array}{l}\text {. Reduced myocardial infarct size, } \\
\text {. Improved hemodynamic parameters } \\
\text {. Increase capilary density } \\
\text {. Reduced inflammation }\end{array}$ & $\begin{array}{l}\text { eNOS, downstream factor in the VEGG signaling, through } \\
\text { activation of Nitric Oxide (NO) can increase stem cells } \\
\text { angiogenic differentiation and survival. }\end{array}$ & [144] \\
\hline & IGF- 1 and HGF & $\begin{array}{l}\text { IM injection, co-injection of } 25 \times 10^{6} \\
\text { IGG-1-paMSCs modified celll with } \\
25 \times 10^{6} \mathrm{HGF} \text {-paMSCs modified cells }\end{array}$ & Pig & $\begin{array}{l}\text { - Promote angiogenic processes in ischemic tissue } \\
\text { - Although cardiac function parameters were not } \\
\text { significantly improved, cell retention and IGF-1 } \\
\text { overexpression was confirmed within the moocardium }\end{array}$ & $\begin{array}{l}\text { Enhanced activation of IGF-1R/PI3K/AKT signaling and } \\
\text { secretion of VEGF. }\end{array}$ & [145] \\
\hline & PKCE & $\begin{array}{l}\text { IM injection, } 10^{6} \mathrm{PKCE}-\mathrm{MSCs} \\
\text { modified cells }\end{array}$ & Rat & $\begin{array}{l}\text { Reduced infarct size and cell apoptosis } \\
\text { - Increased angiogenesis into the infarcted }\end{array}$ & $\begin{array}{l}\text { Enhance activation of SDF-1, CXCR 4, PI3K and } \\
\text { phosphorylated AKT into the MSCs and increase expression } \\
\text { of MSC survival and VEEFF, bFFF, TGFF, CTnI, vWF, SMA and } \\
\text { factor VIII expression. }\end{array}$ & [146] \\
\hline & midkine & $\begin{array}{l}\text { IM injection, } 5 \times 10^{6} \text { midkine }- \text { MSCs } \\
\text { modified cells }\end{array}$ & Rat & $\begin{array}{l}\text { - Prevented hypoxia-induced MSC apoptosis and exert } \\
\text { MSC cytoprotection in In vitro condition. } \\
\text { - Improvised cardiac function }\end{array}$ & $\begin{array}{l}\text { Enhance activation of VEGF, IGF-1, SDF-1 and TGF- } \beta \\
\text { signaling pathways. }\end{array}$ & [147] \\
\hline & PKG1 & $\begin{array}{l}\text { IM injection, } 2 \times 10^{6} \text { PKG1-MSCs } \\
\text { modified cells }\end{array}$ & Rat & $\begin{array}{l}\text {. Improvement heart function indices induding ejection } \\
\text { fraction and fractional shortening } \\
\text {. Improved infarct size and also blood vessel density }\end{array}$ & $\begin{array}{l}\text { Enhance activation of ant-apoptotic proteins such pAkt, } \\
\text { pGSK3 } \beta \text {, and Bcl- } 2 \text { improves cell survival and increase } \\
\text { angiogenesis through increasing expression of HGF, FFGF, } \\
\text { SDF-1 and Ang- } 1 \text { factors. }\end{array}$ & [148] \\
\hline & VEGF plus PDGF & $\begin{array}{l}\text { IV injection, } 5 \times 105 \text { VEGF plus PDGF } \\
\text { - human umbilical cord blood derived } \\
\text { CD133+/CD34+ modified cells }\end{array}$ & Rat & $\begin{array}{l}\text { - Improvised rat myocardial function } \\
\text { - Upregulation of tissue connexin } 4 \text { and pro-angiogenic } \\
\text { molecules }\end{array}$ & $\begin{array}{l}\text { VEGF- PDGF through activation of pro-angiogenic factors } \\
\text { including VEGF, pNNSS3, NOS2 and GSKK and connexin } 433 \text {, } \\
\text { gap junctional protein, improves stem cells function. }\end{array}$ & [113] \\
\hline \multirow{5}{*}{$\begin{array}{l}\text { Using of anti-inflammatory drugs } \\
\text { and agents }\end{array}$} & $\begin{array}{l}\text { HGF and IGF-1 co- } \\
\text { transplantation }\end{array}$ & $\begin{array}{l}\text { IM injection of } 2 \mu \mathrm{g} \mathrm{HGF}+2 \mu \mathrm{g} \text { IGF-1 } \\
\text { with } 1 \times 10^{7} \mathrm{BMSCS}\end{array}$ & Rabbit & $\begin{array}{l}\text { Improved cardiac function and LV remodeling } \\
\text { Reduced implanted BMSC apoptosis } \\
\text {. Induced myocardial differentiation. }\end{array}$ & $\begin{array}{l}\text { Enhance activation of IGF-1R/PI3K/AKT signaling and } \\
\text { secretion of VEGF. }\end{array}$ & [149] \\
\hline & $\begin{array}{l}\text { HIF-1 } 1 \alpha \text { co- } \\
\text { transplantation }\end{array}$ & $\begin{array}{l}\text { IM injection, HIF-1 } 1 \alpha\left(6 \times 10^{9} \text { plate }\right. \\
\text { forming unit) with MSCs }\left(1 \times 10^{\circ}\right)\end{array}$ & Rat & $\begin{array}{l}\text { - Improved cardiac function } \\
\text {. Increased angiogenesis }\end{array}$ & $\begin{array}{l}\text { Enhance activation of angiogenic and anti-apoptotic } \\
\text { mechanisms through increasing VEGF and SDF-1 } \alpha \text { signaling. }\end{array}$ & [150] \\
\hline & $\begin{array}{l}\text { SDF-1 co- } \\
\text { transplantation }\end{array}$ & $\begin{array}{l}50 \mathrm{ng} / \mathrm{mL} \mathrm{SDF}-1 \text { for } 60 \min \text { with IM } \\
\text { injection of } 5 \times 10^{5} \text { MSCs }\end{array}$ & Rat & $\begin{array}{l}\text { - improved myocardial function and vascular density } \\
\text { Suppressed implanted MSCs apoptosis, enhances their } \\
\text { survival and engraftment. }\end{array}$ & Enhance activation of $\mathrm{SDF} / \mathrm{CXCR} 4$ signaling pathway. & [151] \\
\hline & Atorvastatin & $\begin{array}{l}\text { ATV was given by gastric gavage } 2 \mathrm{~h} \\
\text { prior to } \mathrm{MI} \\
(20 \mathrm{mg} / \mathrm{kg} \text { and continued for } 4 \\
\text { weeks } 10 \mathrm{mg} / \mathrm{kg} / \mathrm{dayy} \text {. with IM } \\
\text { injection of } 5 \times 10^{5} \mathrm{MSCS}\end{array}$ & Rat & $\begin{array}{l}\text { - Improved post-infarct inflammatory microenvironment } \\
\text {. Increase regenereation potentiala and efficacy of the } \\
\text { implanted MSCs }\end{array}$ & $\begin{array}{l}\text { Inhibition of RhoA/ROCK/ERK signaling pathway into the } \\
\text { AMI micro environment. }\end{array}$ & [152] \\
\hline & Atorvastatin & $\begin{array}{l}\text { ATV was given } \\
10 \mathrm{mg} / \mathrm{kg} / \mathrm{day}(14 \text { days) with IM } \\
\text { injection of } 1 \times 10^{6} \mathrm{ASCS}\end{array}$ & Rat & $\begin{array}{l}\text { - Improved post-infarct inflammatory microenvironment } \\
\text {. Increase regeneration potential and efficacy of the } \\
\text { implanted ASCS. }\end{array}$ & $\begin{array}{l}\text { Inhibition infittration of inflammatory cells, } \\
\text { myeloperoxidase activity, inflammatory cytokines (VCAM-1, } \\
\text { TNF-a, Hs-CRP) expression, and Bax protein expression. } \\
\text { Also increase survival and differentiation of inmplanted } \\
\text { ASCs into the AMI microenvironment. }\end{array}$ & [153] \\
\hline
\end{tabular}




\section{Cellular Physiology Cell Physiol Biochem 2019;53:887-909

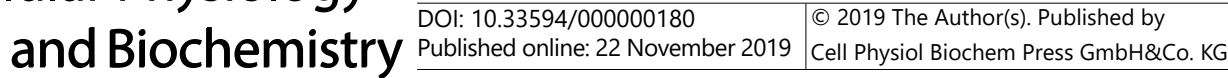 \\ Khodayari et al.: AMI Microenvironment: SCs Death \& Regeneration}

According to an experimental study in a murine model of MI, co-transplantation of endothelial progenitor cells (EPCs) with MSCs by an abdominal muscle-derived patch could significantly improve the cardiac function and increase the efficiency of myocardial infarction cell therapy. They also reported a significant increase in survival and angiogenic differentiation of implanted EPCs [96]. Recently, co-delivery of the C-Kit ${ }^{+} \mathrm{CSCs}$ with the BMMSCs in a rat AMI model enhanced angiogenesis, improved cardiac function, and increased donor cell survival and proliferation. They proved that expression of angiogenic inducer factors like VEGF, angiopoietin-1 (Ang-1), EGF, and platelet-derived growth factor-b (PDGF-b) from the BM-MSCs and activation of AKT signaling pathway in the $\mathrm{C}-\mathrm{Kit}^{+} \mathrm{CSC}$ s were the key mechanisms in this regenerative response [97]. Therefore, the beneficial effects of MSCs on the survival and function of co-transplanted cells are linked with MSCs paracrine/autocrine activity (Table 2).

Application of the SCs-derived secretomes and exosomes can be considered as an appropriate approach for increasing the efficiency of the heart regeneration. Typically, exosomes (30-100 nm cellular vesicles) mediate cell-cell micro-communication by their essential functional molecules such as nucleotides, proteins, and bioactive lipids. These small membrane vesicles are derived from various SCs such as MSCs [98, 99]. MSCs-secreted exosomes have a critical role in the modulation of post-infarcted myocardium healing. An experimental study on the AMI rat models has demonstrated that MSCs-derived exosomes could significantly promote the myocardium function early after heart injury indication via reprogramming the AMI inflammatory microenvironment. These MSCs-secreted exosomes could be carefully uptaken by the VECs and also increase angiogenesis response of the human umbilical vein endothelial cell (HUVECs) as well as suppress the inflammatory leucocytes proliferation [100]. Consequently, exosomes secreted from the human CD34 ${ }^{+}$cells may promote the regenerative responses in an injured myocardium through stimulation of endogenous CSPCs angiogenic differentiation [101]. Moreover, injection of ESC-derived exosomes could elevate endogenous cardiac regeneration and function in an animal AMI model. Apparently, the ESC-derived exosomes can directly enhance the survival and functions of the $\mathrm{C}-\mathrm{Kit}^{+} \mathrm{CPCs}$ and ultimately increase generation of new CMCs in the ischemic heart (Table 2).

In addition to the exosomes, using the SCs secretomes is another compelling option to normalize AMI microenvironment. The interaction between the infarcted myocardial cells and the stem cell's secretomes via regulating different signaling pathways can protect damaged cells and promote the endogenous functions of CSPCs. Using Sca-1 $1^{+} /$CD31- CSCs secretomes could remarkably protect CMCs from the hypoxia-induced apoptosis under the in vitro condition. These protective impacts might have resulted from activation of monocyte chemotactic protein-1(MCP-1)-dependent mechanism [102]. Additionally, the analysis on the Sca-1 $1^{+}$CD 31- CSCs secretomes showed that EGF, TGF- $\beta 1$, IGF-1, IGF-2, MCP-1, hepatocyte growth factor (HGF), and IL- 6 are the main growth factors and cytokines released by Sca- $1^{+}$ CSCs into the conditioned medium [102]. Increasing the resistance of implanted SCs against the adverse AMI microenvironment is another approach for improving the cell therapy efficacy (Table 2).

Hypoxia pre-conditioned SCs could notably enhance the therapeutic potency through the expression of different cardioprotective genes together with the secretion of antiinflammatory, anti-apoptotic, and antifibrotic factors [103-105]. Results of microarray gene expression analysis on the hypoxia pre-conditioned human BM-MSCs and BMMNCs have revealed the overexpression of several genes including VEGF, EGF, and matrix metalloproteinase-9 (MMP-9) in the SCs after 24 hours from hypoxic pre-conditioning [106]. In an experimental study on the non-human primate models of AMI, a significant improvement was observed in the animal's heart infarct size and LVEF within 3-90 days postintra-myocardial delivery of the allogeneic hypoxia pre-conditioned MSCs [107]. Further, using cytokines and growth factor-stimulated SCs is another viable approach for optimizing the resistance of implanted SCs to inflammation and increasing SCs survival, proliferation, 
and differentiation under the AMI condition. A series of potent stimulators, including SDF1, IGF-1, VEGF, and IL-10 can be utilized for improving the SCs potential towards the AMI regeneration [108]. Activation of SDF-1/CXCR4 (ligand/receptor) signaling in the SDF1 -stimulated SCs causes a significant increase in the SCs homing, survival, proliferation and differentiation into the infarcted regions [109]. Similarly, pre-treatment of the Sca- $1^{+}$ SCs with IGF-1 can efficiently induce the generation of new CMCs under AMI condition regardless of improving SCs survival [110]. Likewise, IL-10 stimulation could suppress the disruptive effects of pro-inflammatory cytokines on the implanted SCs, which subsequently improves the cell survival via promoting expression of the cell survival Bcl-2 gene [111]. Oxytocin (OT) pre-treated cells also showed a suitable resistant response to the oxidative stress and the inflammatory microenvironment $[112,113]$. OT-mediated signaling pathways could induce PSCs and ASPCs differentiation into the CMCs and the VECs [114]. Based on the intramyocardial implantation of OT-treated UB-MSCs into MI animal models, significant reductions were observed in the rates of the infiltrated inflammatory cells into the infarct zone and level of cardiac fibrosis. Moreover, SCs function and connexin-43 activation were increased [115].

Ex vivo gene-modified cells are another useful method for improving the SCs function into the AMI microenvironment. In this approach, overexpression of growth factors, antiapoptotic, myogenic, angiogenic, and chemoattractant genes is the primary option for increasing the regenerative potential of SCs in an infarcted environment (Table 2). Practically, implantation of the SDF-1-overexpressed MSCs into the rat's infarcted myocardium resulted in a considerable upregulation in the levels of pro-angiogenic stimulators such as the VEGF and endothelial nitric oxide (eNOS), leading to the improvement of the infarct size, the cardiac fibrosis, and the left ventricular wall thickness [116]. Moreover, protein kinase B (PKB or Akt)-overexpressed MSCs significantly inhibited the cardiac fibrosis and improved heart function in the animal AMI model [117]. Compared with non-modified SCs, CXCR4, VEGF, PDGF, and IGF-1 overexpressed SCs have been found to be associated with higher viability and differentiation potential [118-120].

Suppression some of the specific cytokine's activity or their related receptors (anticytokine therapies), blocking the lymphocyte migration and tropism toward the MI microenvironment, and also preventing interaction of monocyte-lymphocyte membrane receptors, have been introduced as some of the primary activities of the anti-inflammatory drugs (Table 2). These biological functions of the anti-inflammatory agents, through modulation of the stressful microenvironment, may improve the efficacy and potential of the SCs regeneration. For instance, statins as 3-hydroxy-3-methyl glutaryl-CoA (HMG CoA) reductase inhibitors are the safe agents for treating several cardiovascular diseases [121]. Atorvastatin is known to be a strong cardiovascular anti-inflammatory agent. A low dosage of atorvastatin was shown to increase the serum level of VEGF [122]. Atorvastatin is capable of supporting implanted SCs function and differentiation via increasing the level of some growth factors. Administration of the atorvastatin before implantation of the MSCs in a swine AMI model could diminish cardiac fibrosis and improve the implanted MSCs survival through controlling MI inflammatory microenvironment [123]. The results of a terminal meta-analysis indicated that treatment with Atorvastatin can improve the effects of implanted MSCs [124]. However, it has been already demonstrated that the cytoprotective effects of atorvastatin on the implanted SCs are completely dose-dependent. Although a considerable protective and heart-regenerative response has been observed in SCs following the administration of atorvastatin in low doses, some preclinical studies have clarified that in high doses, atorvastatin did not have a significant benefit on the regenerative potential of implanted SCs. As an attractive alternative strategy in graft rejection, application of the monoclonal antibodies by the ability to deplete specific T-cell subsets has additionally shown a brilliant output for protecting grafts following long-term tolerance to major histocompatibility complex (MHC) mismatches. In a pre-clinical study by Stuart, et al. (2000), pre-treatment of the host animals with antibodies against CD4, CD8, and CD3 was noted to significantly increase the survival of graft myoblasts via inhibition of the $\mathrm{CD} 4^{+} / \mathrm{CD} 8^{+} \mathrm{T}$ cell and the $\mathrm{NK}$ 


\section{Cellular Physiology Cell Physiol Biochem 2019;53:887-909 \\ \begin{tabular}{ll|l}
\hline DOl: 10.33594/000000180 & (c) 2019 The Author(s). Published by
\end{tabular} \\ and Biochemistry Published online: 22 November 2019 Cell Physiol Biochem Press GmbH\&Co. KG \\ Khodayari et al.: AMI Microenvironment: SCs Death \& Regeneration}

cells [125]. Also, administration of some immunosuppressive agents such as prednisone and cyclosporine could successfully protect the implanted hESC in immunocompetent mice [126]. Taken together, administration of the agents and the drugs can be a viable, safe, and efficient methods for modulation of inflammatory response into the AMI microenvironment, eventually increasing the efficacy of heart SCs-based therapy in the clinical phases.

\section{Conclusion}

While some of the publications and trials are referred the heart SCs therapy as a promised strategy for the subjects of heart regeneration, meta-analysis of previous AMI SCs therapy clinical trials, until 2014, has clearly highlighted that this approach did not has a stable and long-term efficacy for the recovery of the AMI patient's heart functions. This could be related to the primary inflammatory microenvironment responses of the AMI, which is a complex dynamical system. The delivery of SCs to such environments would result in a destructive effect on the function and proliferation of implanted SCs. This is due to the immunologic and inflammation responses of these environments on arrival of new and unwanted cells. Therefore, obtaining effective SCs-based therapy method for heart regeneration requires the proper modulation of AMI inflammatory microenvironment and optimizing implanted SCs against the inflammation. Attention to intensity, level, and phase of the inflammatory response before cell implantation in AMI patients may be the most determinative factor for prognosis of an effective MI cell-based therapy through the selection of a correct intervention time and approach.

\section{Disclosure Statement}

The authors declare they have no conflict of interest.

\section{References}

1 Abela GS, Kalavakunta JK, Janoudi A, Leffler D, Dhar G, Salehi N, Cohn J, Shah I, Karve M, Kotaru VPK:

Frequency of cholesterol crystals in culprit coronary artery aspirate during acute myocardial infarction and their relation to inflammation and myocardial injury. Am J Cardiol 2017;120:1699-1707.

2 Malliaras K, Makkar RR, Smith RR, Cheng K, Wu E, Bonow RO, Marbán L, Mendizabal A, Cingolani E, Johnston PV: Intracoronary cardiosphere-derived cells after myocardial infarction: evidence of therapeutic regeneration in the final 1-year results of the CADUCEUS trial (CArdiosphere-Derived aUtologous stem CElls to reverse ventricUlar dySfunction). J Am Coll Cardiol 2014;63:110-122.

3 Chen Sl, Fang WW, Ye F, Liu YH, Qian J, Shan SJ, Zhang JJ, Chunhua RZ, Liao LM, Lin S: Effect on left ventricular function of intracoronary transplantation of autologous bone marrow mesenchymal stem cell in patients with acute myocardial infarction. Am J Cardiol 2004;94:92-95.

4 Assmus B, Schachinger V, Teupe C, Britten M, Lehmann R, Döbert N, Grünwald F, Aicher A, Urbich C, Martin $\mathrm{H}$ : Transplantation of progenitor cells and regeneration enhancement in acute myocardial infarction (TOPCARE-AMI). Circulation 2002;106:3009-3017.

5 Guan K, Wagner S, Unsöld B, Maier LS, Kaiser D, Hemmerlein B, Nayernia K, Engel W, Hasenfuss G: Generation of functional cardiomyocytes from adult mouse spermatogonial stem cells. Circ Res 2007;100:1615-1625.

6 Torella D, Ellison GM, Karakikes I, Nadal-Ginard B: Growth-factor-mediated cardiac stem cell activation in myocardial regeneration. Nat Rev Cardiol 2007;4:S46.

7 Hatzistergos KE, Quevedo H, Oskouei BN, Hu Q, Feigenbaum GS, Margitich IS, Mazhari R, Boyle AJ, Zambrano JP, Rodriguez JE: Bone marrow mesenchymal stem cells stimulate cardiac stem cell proliferation and differentiation. Circ Res 2010;107:913-922. 


\section{Cellular Physiology Cell Physiol Biochem 2019;53:887-909 \begin{tabular}{ll|l}
\hline DOI: 10.33594/000000180 & (c) 2019 The Author(s). Published by
\end{tabular} and Biochemistry Published online: 22 November 2019 Cell Physiol Biochem Press GmbH\&Co. KG \\ Khodayari et al.: AMI Microenvironment: SCs Death \& Regeneration}

8 Lee SH, Hong JH, Cho KH, Noh JW, Cho HJ: Discrepancy between short-term and long-term effects of bone marrow-derived cell therapy in acute myocardial infarction: a systematic review and meta-analysis. Stem Cell Res Ther 2016;7:153.

9 Mezzaroma E, Toldo S, Farkas D, Seropian IM, Van Tassell BW, Salloum FN, Kannan HR, Menna AC, Voelkel $\mathrm{NF}$, Abbate A: The inflammasome promotes adverse cardiac remodeling following acute myocardial infarction in the mouse. Proc Natl Acad Sci 2011;108:19725-19730.

10 Swirski FK, Nahrendorf M: Leukocyte behavior in atherosclerosis, myocardial infarction, and heart failure. Science 2013;339:161-166.

11 Venkatachalam K, Venkatesan B, Valente AJ, Melby PC, Nandish S, Reusch JE, Clark RA, Chandrasekar B: WISP1, a pro-mitogenic, pro-survival factor, mediates tumor necrosis factor- $\alpha$ (TNF- $\alpha$ )-stimulated cardiac fibroblast proliferation but inhibits TNF- $\alpha$-induced cardiomyocyte death. J Biol Chem 2009;284:1441414427.

12 Suzuki K, Murtuza B, Beauchamp JR, Brand NJ, Barton PJ, Varela-Carver A, Fukushima S, Coppen SR, Partridge TA, Yacoub MH: Role of interleukin- $1 \beta$ in acute inflammation and graft death after cell transplantation to the heart. Circulation 2004;110:II-219-II-224.

13 Oka T, Hikoso S, Yamaguchi O, Taneike M, Takeda T, Tamai T, Oyabu J, Murakawa T, Nakayama H, Nishida K: Mitochondrial DNA that escapes from autophagy causes inflammation and heart failure. Nature 2012;485:251.

14 Hamid T, Xu Y, Ismahil MA, Li Q, Jones SP, Bhatnagar A, Bolli R, Prabhu SD: TNF receptor signaling inhibits cardiomyogenic differentiation of cardiac stem cells and promotes a neuroadrenergic-like fate. Am J Physiol Heart Circ Physiol 2016;311:H1189-H1201.

15 Nayernia K, Nolte J, Michelmann HW, Lee JH, Rathsack K, Drusenheimer N, Dev A, Wulf G, Ehrmann IE, Elliott DJ: In vitro-differentiated embryonic stem cells give rise to male gametes that can generate offspring mice. Dev Cell 2006;11:125-132.

16 Mardanpour P, Nayernia K, Khodayari S, Khodayari H, Molcanyi M, Hescheler J: Application of Stem Cell Technologies to Regenerate Injured Myocardium and Improve Cardiac Function. Cell Physiol Biochem 2019;53:20.

17 Young RA: Control of the embryonic stem cell state. Cell 2011;144:940-954.

18 Zovoilis A, Nolte J, Drusenheimer N, Zechner U, Hada H, Guan K, Hasenfuss G, Nayernia K, Engel W: Multipotent adult germline stem cells and embryonic stem cells have similar microRNA profiles. Mol Hum Reprod 2008;14:521-529.

19 Boheler KR, Czyz J, Tweedie D, Yang HT, Anisimov SV, Wobus AM: Differentiation of pluripotent embryonic stem cells into cardiomyocytes. Circ Res 2002;91:189-201.

20 Bekhite MM, Finkensieper A, Binas S, Müller J, Wetzker R, Figulla HR, Sauer H, Wartenberg M: VEGFmediated PI3K class IA and PKC signaling in cardiomyogenesis and vasculogenesis of mouse embryonic stem cells. J Cell Sci 2011;124:1819-1830.

21 Guan K, Hasenfuss G, Nayernia K, Engel W: Compositions and methods for producing pluripotent cells from adult testis, Patent number EP1943335A2.

22 Mathur A, Loskill P, Shao K, Huebsch N, Hong S, Marcus SG, Marks N, Mandegar M, Conklin BR, Lee LP: Human iPSC-based cardiac microphysiological system for drug screening applications. Sci Rep 2015;5:8883.

23 Shinde V, Srinivasan SP, Henry M, Rotshteyn T, Hescheler J, Rahnenführer J, Grinberg M, Meisig J, Blüthgen $\mathrm{N}$, Waldmann T: Comparison of a teratogenic transcriptome-based predictive test based on human embryonic versus inducible pluripotent stem cells. Stem Cell Res Ther 2016;7:190.

24 Amidi F, Nejad NA, Hoseini MA, Nayernia K, Mazaheri Z, Yamini N, Saeednia S: In vitro differentiation process of human Wharton's jelly mesenchymal stem cells to male germ cells in the presence of gonadal and non-gonadal conditioned media with retinoic acid. In vitro Cell Dev Biol Anim 2015;51:1093-1101.

25 Wagner W, Wein F, Seckinger A, Frankhauser M, Wirkner U, Krause U, Blake J, Schwager C, Eckstein V, Ansorge W: Comparative characteristics of mesenchymal stem cells from human bone marrow, adipose tissue, and umbilical cord blood. Exp Hematol 2005;33:1402-1416.

26 Liu X, Duan B, Cheng Z, Jia X, Mao L, Fu H, Che Y, Ou L, Liu L, Kong D: SDF-1/CXCR4 axis modulates bone marrow mesenchymal stem cell apoptosis, migration and cytokine secretion. Protein Cell 2011;2:845-854. 


\section{Cellular Physiology Cell Physiol Biochem 2019;53:887-909 \begin{tabular}{ll|l} 
and Bioch 2019 The Author(s). Published by \\
\hline
\end{tabular} and BIOChemistry Published online: 22 November 2019 Cell Physiol Biochem Press GmbH\&Co. KG \\ Khodayari et al.: AMI Microenvironment: SCs Death \& Regeneration}

27 Hodgkinson CP, Naidoo V, Patti KG, Gomez JA, Schmeckpeper J, Zhang Z, Davis B, Pratt RE, Mirotsou M, Dzau VJ: Abi3bp is a multifunctional autocrine/paracrine factor that regulates mesenchymal stem cell biology. Stem Cells 2013;31:1669-1682.

28 Khodayari S, Khodayari H, Alizadeh AM: A glance into the future cardiac stem cells. Tehran Univ Med J 2016;74:223-235.

29 Matsuura K, Nagai T, Nishigaki N, Oyama T, Nishi J, Wada H, Sano M, Toko H, Akazawa H, Sato T: Adult cardiac Sca-1-positive cells differentiate into beating cardiomyocytes. J Biol Chem 2004;279:11384-11391.

30 Kubo H, Jaleel N, Kumarapeli A, Berretta RM, Bratinov G, Shan X, Wang H, Houser SR, Margulies KB: Increased cardiac myocyte progenitors in failing human hearts. Circulation 2008;118:649.

31 Bearzi C, Rota M, Hosoda T, Tillmanns J, Nascimbene A, De Angelis A, Yasuzawa-Amano S, Trofimova I, Siggins RW, LeCapitaine N: Human cardiac stem cells. Proc Natl Acad Sci 2007;104:14068-14073.

32 Bellio MA, Rodrigues CO, Landin AM, Hatzistergos KE, Kuznetsov J, Florea V, Valasaki K, Khan A, Hare JM, Schulman IH: Physiological and hypoxic oxygen concentration differentially regulates human c-Kit+ cardiac stem cell proliferation and migration. Am J Physiol Heart Circ Physiol 2016;311:H1509-H1519.

33 Li W, Liu H, Liu P, Yin D, Zhang S, Zhao J: Sphingosylphosphorylcholine promotes the differentiation of resident Sca-1 positive cardiac stem cells to cardiomyocytes through lipid raft/JNK/STAT3 and $\beta$-catenin signaling pathways. Biochim Biophys Acta 2016;1863:1579-1588.

34 Shiba Y, Gomibuchi T, Seto T, Wada Y, Ichimura H, Tanaka Y, Ogasawara T, Okada K, Shiba N, Sakamoto K: Allogeneic transplantation of iPS cell-derived cardiomyocytes regenerates primate hearts. Nature 2016;538:388.

35 Menasche P, Vanneaux V, Fabreguettes JR, Bel A, Tosca L, Garcia S, Bellamy V, Farouz Y, Pouly J, Damour O: Towards a clinical use of human embryonic stem cell-derived cardiac progenitors: a translational experience. Eur Heart J 2014;36:743-750.

36 Robbers LF, Nijveldt R, Beek AM, Hirsch A, van der Laan AM, Delewi R, van der Vleuten PA, Tio RA, Tijssen JG, Hofman MB: Cell therapy in reperfused acute myocardial infarction does not improve the recovery of perfusion in the infarcted myocardium: a cardiac MR imaging study. Radiology 2014;272:113-122.

37 Behfar A, Perez-Terzic C, Faustino RS, Arrell DK, Hodgson DM, Yamada S, Puceat M, Niederländer N, Alekseev AE, Zingman LV: Cardiopoietic programming of embryonic stem cells for tumor-free heart repair. J Exp Med 2007;204:405-420.

38 Templin C, Zweigerdt R, Schwanke K, Olmer R, Ghadri JR, Emmert MY, Müller E, Küest SM, Cohrs S, Schibli R: Transplantation and tracking of human-induced pluripotent stem cells in a pig model of myocardial infarction: assessment of cell survival, engraftment, and distribution by hybrid single photon emission computed tomography/computed tomography of sodium iodide symporter transgene expression. Circulation 2012;126:430-439.

39 Chong JJ, Yang X, Don CW, Minami E, Liu Y-W, Weyers JJ, Mahoney WM, Van Biber B, Cook SM, Palpant NJ: Human embryonic-stem-cell-derived cardiomyocytes regenerate non-human primate hearts. Nature 2014;510:273.

40 Postovit LM, Margaryan NV, Seftor EA, Kirschmann DA, Lipavsky A, Wheaton WW, Abbott DE, Seftor RE, Hendrix MJ: Human embryonic stem cell microenvironment suppresses the tumorigenic phenotype of aggressive cancer cells. Proc Natl Acad Sci 2008;105:4329-4334.

41 Tan Y, Ooi S, Wang L: Immunogenicity and tumorigenicity of pluripotent stem cells and their derivatives: genetic and epigenetic perspectives. Current Stem Cell Res Ther 2014;9:63-72.

42 Gao LR, Chen Y, Zhang NK, Yang XL, Liu HL, Wang ZG, Yan XY, Wang Y, Zhu ZM, Li TC: Intracoronary infusion of Wharton's jelly-derived mesenchymal stem cells in acute myocardial infarction: double-blind, randomized controlled trial. BMC Med 2015;13:162.

43 Huang R, Yao K, Sun A, Qian J, Ge L, Zhang Y, Niu Y, Wang K, Zou Y, Ge J: Timing for intracoronary administration of bone marrow mononuclear cells after acute ST-elevation myocardial infarction: a pilot study. Stem Cell Res Ther 2015;6:112.

44 Hu X, Huang X, Yang Q, Wang L, Sun J, Zhan H, Lin J, Pu Z, Jiang J, Sun Y: Safety and efficacy of intracoronary hypoxia-preconditioned bone marrow mononuclear cell administration for acute myocardial infarction patients: The CHINA-AMI randomized controlled trial. Int J Cardiol 2015;184:446-451.

45 Goradel NH, Hour FG, Negahdari B, Malekshahi ZV, Hashemzehi M, Masoudifar A, Mirzaei H: Stem Cell Therapy: A New Therapeutic Option for Cardiovascular Diseases. J Cell Biochem 2018;119:95-104. 


\section{Cellular Physiology Cell Physiol Biochem 2019;53:887-909 \begin{tabular}{ll|l} 
and Bioch 2019 The Author(s). Published by \\
\hline
\end{tabular} and BIOChemistry Published online: 22 November 2019 Cell Physiol Biochem Press GmbH\&Co. KG \\ Khodayari et al.: AMI Microenvironment: SCs Death \& Regeneration}

46 Kawamoto A, Tkebuchava T, Yamaguchi J, Nishimura H, Yoon YS, Milliken C, Uchida S, Masuo O, Iwaguro H, Ma H, Hanley A, Silver M, Kearney M, Losordo DW, Isner JM, Asahara T: Intramyocardial transplantation of autologous endothelial progenitor cells for therapeutic neovascularization of myocardial ischemia. Circulation 2003;107:461-468.

47 Strauer BE, Steinhoff G: 10 years of intracoronary and intramyocardial bone marrow stem cell therapy of the heart: from the methodological origin to clinical practice. J Am Coll Cardiol 2011;58:1095-1104.

48 Nelson DM, Ma Z, Fujimoto KL, Hashizume R, Wagner WR: Intra-myocardial biomaterial injection therapy in the treatment of heart failure: Materials, outcomes and challenges. Acta Biomater 2011;7:1-15.

49 Krause K, Jaquet K, Schneider C, Haupt S, Lioznov MV, Otte KM, Kuck KH: Percutaneous intramyocardial stem cell injection in patients with acute myocardial infarction: first-in-man study. Heart 2009;95:11451152.

50 Urbanek K, Rota M, Cascapera S, Bearzi C, Nascimbene A, De Angelis A, Hosoda T, Chimenti S, Baker M, Limana F: Cardiac stem cells possess growth factor-receptor systems that after activation regenerate the infarcted myocardium, improving ventricular function and long-term survival. Circ Res 2005;97:663-673.

51 Bagheri F, Khori V, Alizadeh AM, Khalighfard S, Khodayari S, Khodayari H: Reactive oxygen speciesmediated cardiac-reperfusion injury: mechanisms and therapies. Life Sci 2016;165:43-55.

52 Faghihi M, Alizadeh AM, Khori V, Latifpour M, Khodayari S: The role of nitric oxide, reactive oxygen species, and protein kinase $C$ in oxytocin-induced cardioprotection in ischemic rat heart. Peptides 2012;37:314319.

53 Venardos KM, Perkins A, Headrick J, Kaye DM: Myocardial ischemia-reperfusion injury, antioxidant enzyme systems, and selenium: a review. Curr Med Chem 2007;14:1539-1549.

54 Fan H, Sun B, Gu Q Lafond-Walker A, Cao S, Becker LC: Oxygen radicals trigger activation of NF-kappaB and AP-1 and upregulation of ICAM-1 in reperfused canine heart. Am J Physiol Heart Circ Physiol 2002;282:H1778-1786.

55 Timmers L, Pasterkamp G, de Hoog VC, Arslan F, Appelman Y, de Kleijn DP: The innate immune response in reperfused myocardium. Cardiovasc Res 2012;94:276-283.

56 Andrassy M, Volz HC, Igwe JC, Funke B, Eichberger SN, Kaya Z, Buss S, Autschbach F, Pleger ST, Lukic IK, Bea F, Hardt SE, Humpert PM, Bianchi ME, Mairbaurl H, Nawroth PP, Remppis A, Katus HA, Bierhaus A: Highmobility group box-1 in ischemia-reperfusion injury of the heart. Circulation 2008;117:3216-3226.

57 Ding HS, Yang J, Chen P, Yang J, Bo SQ, Ding JW, Yu QQ: The HMGB1-TLR4 axis contributes to myocardial ischemia/reperfusion injury via regulation of cardiomyocyte apoptosis. Gene 2013;527:389-393.

58 Demiryilmaz I, Sener E, Cetin N, Altuner D, Akcay F, Suleyman H: A comparative investigation of biochemical and histopathological effects of thiamine and thiamine pyrophosphate on ischemia-reperfusion induced oxidative damage in rat ovarian tissue. Arch Pharm Res 2013;36:1133-1139.

59 Nahrendorf M, Swirski FK, Aikawa E, Stangenberg L, Wurdinger T, Figueiredo JL, Libby P, Weissleder R, Pittet MJ: The healing myocardium sequentially mobilizes two monocyte subsets with divergent and complementary functions. J Exp Med 2007;204:3037-3047.

60 Leuschner F, Rauch PJ, Ueno T, Gorbatov R, Marinelli B, Lee WW, Dutta P, Wei Y, Robbins C, Iwamoto Y: Rapid monocyte kinetics in acute myocardial infarction are sustained by extramedullary monocytopoiesis. J Exp Med 2012;209:123-137.

61 Hofmann U, Beyersdorf N, Weirather J, Podolskaya A, Bauersachs J, Ertl G, Kerkau T, Frantz S: Activation of CD4+ T lymphocytes improves wound healing and survival after experimental myocardial infarction in mice. Circulation 2012;125:1652-1663.

62 Dutta P, Nahrendorf M: Monocytes in myocardial infarction. Arterioscler Thromb Vasc Biol 2015;35:10661070.

63 Anzai A, Anzai T, Nagai S, Maekawa Y, Naito K, Kaneko H, Sugano Y, Takahashi T, Abe H, Mochizuki S: Regulatory role of dendritic cells in postinfarction healing and left ventricular remodeling. Circulation 2012;125:1234-1245.

64 Frangogiannis NG: The inflammatory response in myocardial injury, repair, and remodelling. Nat Rev Cardiol 2014;11:255.

65 Frangogiannis NG, Lindsey ML, Michael LH, Youker KA, Bressler RB, Mendoza LH, Spengler RN, Smith CW, Entman ML: Resident cardiac mast cells degranulate and release preformed TNF- $\alpha$, initiating the cytokine cascade in experimental canine myocardial ischemia/reperfusion. Circulation 1998;98:699-710. 


\section{Cellular Physiology Cell Physiol Biochem 2019;53:887-909 \begin{tabular}{ll|l}
\hline DOl: 10.33594/000000180 & (c) 2019 The Author(s). Published by
\end{tabular} and Biochemistry Published online: 22 November 2019 Cell Physiol Biochem Press GmbH\&Co. KG \\ Khodayari et al.: AMI Microenvironment: SCs Death \& Regeneration}

66 Engel D, Peshock R, Armstong RC, Sivasubramanian N, Mann DL: Cardiac myocyte apoptosis provokes adverse cardiac remodeling in transgenic mice with targeted TNF overexpression. Am J Physiol Heart Circ Physiol 2004;287:H1303-H1311.

67 Sun M, Dawood F, Wen WH, Chen M, Dixon I, Kirshenbaum LA, Liu PP: Excessive tumor necrosis factor activation after infarction contributes to susceptibility of myocardial rupture and left ventricular dysfunction. Circulation 2004;110:3221-3228.

68 Dinarello CA: Biologic basis for interleukin-1 in disease. Blood 1996;87:2095-2147.

69 Van Tassell BW, Toldo S, Mezzaroma E, Abbate A: Targeting interleukin-1 in heart disease. Circulation 2013;128:1910-1923.

70 Suzuki K, Murtuza B, Smolenski RT, Sammut IA, Suzuki N, Kaneda Y, Yacoub MH: Overexpression of interleukin-1 receptor antagonist provides cardioprotection against ischemia-reperfusion injury associated with reduction in apoptosis. Circulation 2001;104:I308-I3.

71 Kukielka GL, Smith CW, Manning AM, Youker KA, Michael LH, Entman ML: Induction of interleukin-6 synthesis in the myocardium: potential role in postreperfusion inflammatory injury. Circulation 1995;92:1866-1875.

72 Aoyama T, Takimoto Y, Pennica D, Inoue R, Shinoda E, Hattori R, Yui Y, Sasayama S: Augmented expression of cardiotrophin-1 and its receptor component, gp130, in both left and right ventricles after myocardial infarction in the rat. J Mol Cell Cardiol 2000;32:1821-1830.

73 Laflamme MA, Murry CE: Regenerating the heart. Nat Biotechnol 2005;23:845.

74 Toma C, Pittenger MF, Cahill KS, Byrne BJ, Kessler PD: Human mesenchymal stem cells differentiate to a cardiomyocyte phenotype in the adult murine heart. Circulation 2002;105:93-98.

75 Reinecke H, Murry CE: Transmural replacement of myocardium after skeletal myoblast grafting into the heart: too much of a good thing? Cardiovasc Pathol 2000;9:337-344.

76 Chiong M, Wang Z, Pedrozo Z, Cao D, Troncoso R, Ibacache M, Criollo A, Nemchenko A, Hill J, Lavandero S: Cardiomyocyte death: mechanisms and translational implications. Cell Death Dis 2011;2:e244.

77 Spaggiari GM, Capobianco A, Becchetti S, Mingari MC, Moretta L: Mesenchymal stem cell-natural killer cell interactions: evidence that activated NK cells are capable of killing MSCs, whereas MSCs can inhibit IL-2induced NK-cell proliferation. Blood 2006;107:1484-1490.

78 Perkins ND: Integrating cell-signalling pathways with NF- $\mathrm{BB}$ and IKK function. Nat Rev Mol Cell Biol 2007;8:49.

79 Perrelli MG, Pagliaro P, Penna C: Ischemia/reperfusion injury and cardioprotective mechanisms: role of mitochondria and reactive oxygen species. World J Cardiol 2011;3:186.

80 Laurindo FR, Pescatore LA, de Castro Fernandes D: Protein disulfide isomerase in redox cell signaling and homeostasis. Free Radic Biol Med 2012;52:1954-1969.

81 Nishida K, Kyoi S, Yamaguchi O, Sadoshima J, Otsu K: The role of autophagy in the heart. Cell Death Differ 2009;16:31.

82 Rusten LS, Smeland EB, Jacobsen FW, Lien E, Lesslauer W, Loetscher H, Dubois CM, Jacobsen S: Tumor necrosis factor-alpha inhibits stem cell factor-induced proliferation of human bone marrow progenitor cells in vitro. Role of p55 and p75 tumor necrosis factor receptors. J Clin Invest 1994;94:165-172.

83 Chiriac A, Terzic A, Park S, Ikeda Y, Faustino R, Nelson TJ: SDF-1-enhanced cardiogenesis requires CXCR4 induction in pluripotent stem cells. J Cardiovasc Transl Res 2010;3:674-682.

84 Markel TA, Crisostomo PR, Wang M, Herring CM, Meldrum DR: Activation of individual tumor necrosis factor receptors differentially affects stem cell growth factor and cytokine production. Am J Physiol Gastrointest Liver Physiol 2007;293:G657-G662.

85 Murtuza B, Suzuki K, Bou-Gharios G, Beauchamp JR, Smolenski RT, Partridge TA, Yacoub MH: Transplantation of skeletal myoblasts secreting an IL-1 inhibitor modulates adverse remodeling in infarcted murine myocardium. Proc Natl Acad Sci 2004;101:4216-4221.

86 Wei R, Yang J, Gao M, Wang H, Hou W, Mu Y, Chen G, Hong T: Infarcted cardiac microenvironment may hinder cardiac lineage differentiation of human embryonic stem cells. Cell Biol Int 2016;40:1235-1246.

87 Groschel C, Hubscher D, Nolte J, Monecke S, Sasse A, Elsner L, Paulus W, Trenkwalder C, Polic B, Mansouri A, Guan K, Dressel R: Efficient Killing of Murine Pluripotent Stem Cells by Natural Killer (NK) Cells Requires Activation by Cytokines and Partly Depends on the Activating NK Receptor NKG2D. Front Immunol 2017;8:870. 


\section{Cellular Physiology Cell Physiol Biochem 2019;53:887-909 \begin{tabular}{l|l|l} 
and Biol: 10.33594/000000180 2019 The Author(s). Published by \\
\hline
\end{tabular} and BIOChemistry Published online: 22 November 2019 Cell Physiol Biochem Press GmbH\&Co. KG \\ Khodayari et al.: AMI Microenvironment: SCs Death \& Regeneration}

88 Magliocca JF, Held IK, Odorico JS: Undifferentiated murine embryonic stem cells cannot induce portal tolerance but may possess immune privilege secondary to reduced major histocompatibility complex antigen expression. Stem Cells Dev 2006;15:707-717.

89 Chen YR, Li Y, Chen L, Yang XC, Su PX, Cai J: The infarcted cardiac microenvironment cannot selectively promote embryonic stem cell differentiation into cardiomyocytes. Cardiovasc Pathol 2011;20:77-83.

90 Kyurkchiev D, Ivanova-Todorova E, Bochev I, Mourdjeva M, Kyurkchiev S: Differences between adipose tissue-derived mesenchymal stem cells and bone marrow-derived mesenchymal stem cells as regulators of the immune response; Stem Cells and Cancer Stem Cells, Volume 10, Springer, 2013, pp 71-84.

91 Patel SA, Meyer JR, Greco SJ, Corcoran KE, Bryan M, Rameshwar P: Mesenchymal stem cells protect breast cancer cells through regulatory T cells: role of mesenchymal stem cell-derived TGF- $\beta$. J Immunol 2010;184:5885-5894.

92 Ringe J, Strassburg S, Neumann K, Endres M, Notter M, Burmester GR, Kaps C, Sittinger M: Towards in situ tissue repair: human mesenchymal stem cells express chemokine receptors CXCR1, CXCR2 and CCR2, and migrate upon stimulation with CXCL8 but not CCL2. J Cell Biochem 2007;101:135-146.

93 Chen L, Tredget EE, Wu PY, Wu Y: Paracrine factors of mesenchymal stem cells recruit macrophages and endothelial lineage cells and enhance wound healing. PloS One 2008;3:e1886.

94 Sioud M, Mobergslien A, Boudabous A, Fløisand Y: Mesenchymal stem cell-mediated T cell suppression occurs through secreted galectins. Int J Oncol 2011;38:385-390.

95 Ren G, Zhao X, Zhang L, Zhang J, L'Huillier A, Ling W, Roberts AI, Le AD, Shi S, Shao C: Inflammatory cytokine-induced intercellular adhesion molecule- 1 and vascular cell adhesion molecule- 1 in mesenchymal stem cells are critical for immunosuppression. J Immunol 2010;184:2321-2328.

96 Derval N, Barandon L, Dufourcq P, Leroux L, Lamazière J-MD, Daret D, Couffinhal T, Duplàa C: Epicardial deposition of endothelial progenitor and mesenchymal stem cells in a coated muscle patch after myocardial infarction in a murine model. Eur J Cardiothorac Surg 2008;34:248-254.

97 Bao L, Meng Q, Li Y, Deng S, Yu Z, Liu Z, Zhang L, Fan H: C-Kit Positive Cardiac Stem Cells and Bone MarrowDerived Mesenchymal Stem Cells Synergistically Enhance Angiogenesis and Improve Cardiac Function After Myocardial Infarction in a Paracrine Manner. J Card Fail 2017;23:403-415.

98 Arslan F, Lai RC, Smeets MB, Akeroyd L, Choo A, Aguor EN, Timmers L, van Rijen HV, Doevendans PA, Pasterkamp G, Lim SK, de Kleijn DP: Mesenchymal stem cell-derived exosomes increase ATP levels, decrease oxidative stress and activate PI3K/Akt pathway to enhance myocardial viability and prevent adverse remodeling after myocardial ischemia/reperfusion injury. Stem Cell Res 2013;10:301-312.

99 Vrijsen KR, Sluijter JP, Schuchardt MW, van Balkom BW, Noort WA, Chamuleau SA, Doevendans PA: Cardiomyocyte progenitor cell-derived exosomes stimulate migration of endothelial cells. J Cell Mol Med 2010;14:1064-1070.

100 Teng X, Chen L, Chen W, Yang J, Yang Z, Shen Z: Mesenchymal Stem Cell-Derived Exosomes Improve the Microenvironment of Infarcted Myocardium Contributing to Angiogenesis and Anti-Inflammation. Cell Physiol Biochem 2015;37:2415-2424.

101 Sahoo S, Klychko E, Thorne T, Misener S, Schultz KM, Millay M, Ito A, Liu T, Kamide C, Agrawal H, Perlman H, Qin G, Kishore R, Losordo DW: Exosomes from human CD34(+) stem cells mediate their proangiogenic paracrine activity. Circ Res 2011;109:724-728.

102 Park CY, Choi SC, Kim JH, Choi JH, Joo HJ, Hong SJ, Lim DS: Cardiac Stem Cell Secretome Protects Cardiomyocytes from Hypoxic Injury Partly via Monocyte Chemotactic Protein-1-Dependent Mechanism. Int J Mol Sci 2016;17:pii:E800.

103 Rosova I, Dao M, Capoccia B, Link D, Nolta JA: Hypoxic preconditioning results in increased motility and improved therapeutic potential of human mesenchymal stem cells. Stem Cells 2008;26:2173-2182.

104 Chen P, Wu R, Zhu W, Jiang Z, Xu Y, Chen H, Zhang Z, Chen H, Zhang L, Yu H, Wang J, Hu X: Hypoxia preconditioned mesenchymal stem cells prevent cardiac fibroblast activation and collagen production via leptin. PLoS One 2014;9:e103587.

105 Hu X, Huang X, Yang Q, Wang L, Sun J, Zhan H, Lin J, Pu Z, Jiang J, Sun Y, Xiang M, Liu X, Xie X, Yu X, Chen Z, Tse HF, Zhang J, Wang J: Safety and efficacy of intracoronary hypoxia-preconditioned bone marrow mononuclear cell administration for acute myocardial infarction patients: The CHINA-AMI randomized controlled trial. Int J Cardiol 2015;184:446-451.

106 Ohnishi S, Yasuda T, Kitamura S, Nagaya N: Effect of hypoxia on gene expression of bone marrow-derived mesenchymal stem cells and mononuclear cells. Stem Cells 2007;25:1166-1177. 


\section{Cellular Physiology Cell Physiol Biochem 2019;53:887-909 \begin{tabular}{l|l|l} 
and Biol: $10.33594 / 000000180$ & 2019 The Author(s). Published by
\end{tabular} and BIOChemistry Published online: 22 November 2019 Cell Physiol Biochem Press GmbH\&Co. KG \\ Khodayari et al.: AMI Microenvironment: SCs Death \& Regeneration}

107 Hu X, Xu Y, Zhong Z, Wu Y, Zhao J, Wang Y, Cheng H, Kong M, Zhang F, Chen Q, Sun J, Li Q, Jin J, Li Q Chen L, Wang C, Zhan H, Fan Y, Yang Q Yu L, et al.: A Large-Scale Investigation of Hypoxia-Preconditioned Allogeneic Mesenchymal Stem Cells for Myocardial Repair in Nonhuman Primates: Paracrine Activity Without Remuscularization. Circ Res 2016;118:970-983.

108 Yu SP, Wei Z, Wei L: Preconditioning strategy in stem cell transplantation therapy. Transl Stroke Res 2013;4:76-88.

109 Petit I, Szyper-Kravitz M, Nagler A, Lahav M, Peled A, Habler L, Ponomaryov T, Taichman RS, ArenzanaSeisdedos F, Fujii N, Sandbank J, Zipori D, Lapidot T: G-CSF induces stem cell mobilization by decreasing bone marrow SDF-1 and up-regulating CXCR4. Nat Immunol 2002;3:687-694.

110 Li N, Pasha Z, Ashraf M: Reversal of ischemic cardiomyopathy with Sca-1+ stem cells modified with multiple growth factors. PLoS One 2014;9:e93645.

111 Abarbanell AM, Coffey AC, Fehrenbacher JW, Beckman DJ, Herrmann JL, Weil B, Meldrum DR: Proinflammatory cytokine effects on mesenchymal stem cell therapy for the ischemic heart. Ann Thorac Surg 2009;88:1036-1043.

112 Kocoglu H, Karaaslan K, Gonca E, Bozdogan O, Gulcu N: Preconditionin effects of dexmedetomidine on myocardial ischemia/reperfusion injury in rats. Curr Ther Res Clin Exp 2008;69:150-158.

113 Jankowski M, Bissonauth V, Gao L, Gangal M, Wang D, Danalache B, Wang Y, Stoyanova E, Cloutier G, Blaise G, Gutkowska J: Anti-inflammatory effect of oxytocin in rat myocardial infarction. Basic Res Cardiol 2010;105:205-218.

114 Paquin J, Danalache BA, Jankowski M, McCann SM, Gutkowska J: Oxytocin induces differentiation of P19 embryonic stem cells to cardiomyocytes. Proc Natl Acad Sci U S A 2002;99:9550-9555.

115 Ahn Y KY, Jo AS, Hong MH, Kwon JS, Shin SM, Jeong MH, Cho JG, Park JC, Kang JC: OXYTOCIN: A PRIMING REAGENT TO COMMIT UCB-MSCS FOR CARDIAC REPAIR-FUNCTION STUDY AND PHASE RETARDATION IMAGING TECHNIQUE OF OXYTOCIN-TREATED UCB-MSC. J Am Coll Cardiol 2010;55:A117.E1092.

116 Tang J, Wang J, Yang J, Kong X, Zheng F, Guo L, Zhang L, Huang Y: Mesenchymal stem cells over-expressing SDF-1 promote angiogenesis and improve heart function in experimental myocardial infarction in rats. Eur J Cardiothorac Surg 2009;36:644-650.

117 Lim SY, Kim YS, Ahn Y, Jeong MH, Hong MH, Joo SY, Nam KI, Cho JG, Kang PM, Park JC: The effects of mesenchymal stem cells transduced with Akt in a porcine myocardial infarction model. Cardiovasc Res 2006;70:530-542.

118 Zhang D, Fan GC, Zhou X, Zhao T, Pasha Z, Xu M, Zhu Y, Ashraf M, Wang Y: Over-expression of CXCR4 on mesenchymal stem cells augments myoangiogenesis in the infarcted myocardium. J Mol Cell Cardiol 2008;44:281-292.

119 Das H, George JC, Joseph M, Das M, Abdulhameed N, Blitz A, Khan M, Sakthivel R, Mao HQ Hoit BD, Kuppusamy P, Pompili VJ: Stem cell therapy with overexpressed VEGF and PDGF genes improves cardiac function in a rat infarct model. PLoS One 2009;4:e7325.

120 Haider H, Jiang S, Idris NM, Ashraf M: IGF-1-overexpressing mesenchymal stem cells accelerate bone marrow stem cell mobilization via paracrine activation of SDF-1alpha/CXCR4 signaling to promote myocardial repair. Circ Res 2008;103:1300-1308.

121 Ke X, Ke B, Wang X, Wu S, Yang R, Hu C: Additive effects of atorvastatin combined with sitagliptin on rats with myocardial infarction: a pilot study. Arch Med Sci 2017;13:956-961.

122 Dworacka M, Krzyzagorska E, Wesolowska A, Borowska M, Iskakova S, Dworacki G: Statins in low doses reduce VEGF and bFGF serum levels in patients with type 2 diabetes mellitus. Pharmacology 2014;93:3238.

123 Song L, Yang YJ, Dong QT, Qian HY, Gao RL, Qiao SB, Shen R, He ZX, Lu MJ, Zhao SH, Geng YJ, Gersh BJ: Atorvastatin enhance efficacy of mesenchymal stem cells treatment for swine myocardial infarction via activation of nitric oxide synthase. PLoS One 2013;8:e65702.

124 Dai G, Xu Q, Luo R, Gao J, Chen H, Deng Y, Li Y, Wang Y, Yuan W, Wu X: Atorvastatin treatment improves effects of implanted mesenchymal stem cells: meta-analysis of animal models with acute myocardial infarction. BMC Cardiovasc Disord 2015;15:170.

125 Hodgetts SI, Beilharz MW, Scalzo AA, Grounds MD: Why do cultured transplanted myoblasts die in vivo? DNA quantification shows enhanced survival of donor male myoblasts in host mice depleted of CD4+ and CD8+ cells or Nk1.1+ cells. Cell Transplant 2000;9:489-502. 


\section{Cellular Physiology Cell Physiol Biochem 2019;53:887-909 \begin{tabular}{l|l|l} 
and Biol: $10.33594 / 000000180$ & 2019 The Author(s). Published by
\end{tabular} and BiOChemistry Published online: 22 November 2019 Cell Physiol Biochem Press GmbH\&Co. KG \\ Khodayari et al.: AMI Microenvironment: SCs Death \& Regeneration}

126 Chan JW, Lieu DK, Huser T, Li RA: Label-free separation of human embryonic stem cells and their cardiac derivatives using Raman spectroscopy. Anal Chem 2009;81:1324-1331.

127 Chong JJ, Yang X, Don CW, Minami E, Liu YW, Weyers JJ, Mahoney WM, Van Biber B, Cook SM, Palpant NJ: Human embryonic-stem-cell-derived cardiomyocytes regenerate non-human primate hearts. Nature 2014;510:273-277.

128 Shiba Y, Gomibuchi T, Seto T, Wada Y, Ichimura H, Tanaka Y, Ogasawara T, Okada K, Shiba N, Sakamoto $\mathrm{K}$ : Allogeneic transplantation of iPS cell-derived cardiomyocytes regenerates primate hearts. Nature 2016;538:388-391.

129 Makkar RR, Smith RR, Cheng K, Malliaras K, Thomson LE, Berman D, Czer LS, Marbán L, Mendizabal A, Johnston PV: Intracoronary cardiosphere-derived cells for heart regeneration after myocardial infarction (CADUCEUS): a prospective, randomised phase 1 trial. Lancet 2012;379:895-904.

130 Bolli R, Chugh AR, D’Amario D, Loughran JH, Stoddard MF, Ikram S, Beache GM, Wagner SG, Leri A, Hosoda T: Cardiac stem cells in patients with ischaemic cardiomyopathy (SCIPIO): initial results of a randomised phase 1 trial. Lancet 2011;378:1847-1857.

131 Assmus B, Leistner DM, Schächinger V, Erbs S, Elsässer A, Haberbosch W, Hambrecht R, Sedding D, Yu J, Corti R: Long-term clinical outcome after intracoronary application of bone marrow-derived mononuclear cells for acute myocardial infarction: migratory capacity of administered cells determines event-free survival. Eur Heart J 2014;35:1275-1283.

132 Sürder D, Manka R, Cicero VL, Moccetti T, Rufibach K, Soncin S, Turchetto L, Radrizzani M, Astori G, Schwitter J: Intracoronary injection of bone marrow derived mononuclear cells, early or late after acute myocardial infarction: effects on global left ventricular function four months results of the SWISS-AMI trial. Circulation 2013;127:1968-1979.

133 Heeger CH, Jaquet K, Thiele H, Zulkarnaen Y, Cuneo A, Haller D, Kivelitz D, Schmidt T, Krause K, Metzner A: Percutaneous, transendocardial injection of bone marrow-derived mononuclear cells in heart failure patients following acute ST-elevation myocardial infarction: ALSTER-Stem Cell trial. EuroIntervention 2012;8:732-742.

134 Penicka M, Horak J, Kobylka P, Pytlik R, Kozak T, Belohlavek O, Lang O, Skalicka H, Simek S, Palecek T: Intracoronary injection of autologous bone marrow-derived mononuclear cells in patients with large anterior acute myocardial infarction. J Am Coll Cardiol 2007;49:2373-2374.

135 Chullikana A, Majumdar AS, Gottipamula S, Krishnamurthy S, Kumar AS, Prakash V, Gupta PK: Randomized, double-blind, phase I/II study of intravenous allogeneic mesenchymal stromal cells in acute myocardial infarction. Cytotherapy 2015;17:250-261.

136 Lee JW, Lee SH, Youn YJ, Ahn MS, Kim JY, Yoo BS, Yoon J, Kwon W, Hong IS, Lee K: A randomized, openlabel, multicenter trial for the safety and efficacy of adult mesenchymal stem cells after acute myocardial infarction. J Korean Med Sci 2014;29:23-31.

137 Rodrigo SF, van Ramshorst J, Hoogslag GE, Boden H, Velders MA, Cannegieter SC, Roelofs H, Al Younis I, Dibbets-Schneider P, Fibbe WE: Intramyocardial injection of autologous bone marrow-derived ex vivo expanded mesenchymal stem cells in acute myocardial infarction patients is feasible and safe up to 5 years of follow-up. J Cardiovasc Transl Res 2013;6:816-825.

138 Gao LR, Pei XT, Ding QA, Chen Y, Zhang NK, Chen HY, Wang ZG, Wang YF, Zhu ZM, Li TC: A critical challenge: dosage-related efficacy and acute complication intracoronary injection of autologous bone marrow mesenchymal stem cells in acute myocardial infarction. Int J Cardiol 2013;168:3191-3199.

139 Bao L, Meng Q, Li Y, Deng S, Yu Z, Liu Z, Zhang L, Fan H: C-Kit Positive Cardiac Stem Cells and Bone MarrowDerived Mesenchymal Stem Cells Synergistically Enhance Angiogenesis and Improve Cardiac Function After Myocardial Infarction in a Paracrine Manner. J Card Fail 2017;23:403-415.

140 Citro L, Naidu S, Hassan F, Kuppusamy ML, Kuppusamy P, Angelos MG, Khan M: Comparison of human induced pluripotent stem-cell derived cardiomyocytes with human mesenchymal stem cells following acute myocardial infarction. PLoS One 2014;9:e116281.

141 Suuronen EJ, Price J, Veinot JP, Ascah K, Kapila V, Guo XW, Wong S, Mesana TG, Ruel M: Comparative effects of mesenchymal progenitor cells, endothelial progenitor cells, or their combination on myocardial infarct regeneration and cardiac function. J Thorac Cardiovasc Surg 2007;134:1249-1258.

142 Katritsis DG, Sotiropoulou PA, Karvouni E, Karabinos I, Korovesis S, Perez SA, Voridis EM, Papamichail M: Transcoronary transplantation of autologous mesenchymal stem cells and endothelial progenitors into infarcted human myocardium. Catheter Cardiovasc Interv 2005;65:321-329. 


\section{Cellular Physiology Cell Physiol Biochem 2019;53:887-909

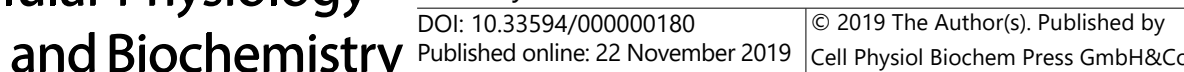 \\ Khodayari et al:: AMI Microenvironment: SCs Death \& Regeneration}

143 Ma J, Zhao Y, Sun L, Sun X, Zhao X, Sun X, Qian H, Xu W, Zhu W: Exosomes derived from AKt-modified human umbilical cord mesenchymal stem cells improve cardiac regeneration and promote angiogenesis via activating platelet-derived growth factor D. Stem Cells Transl Med 2017;6:51-59.

144 Gallet R, Dawkins J, Valle J, Simsolo E, de Couto G, Middleton R, Tseliou E, Luthringer D, Kreke M, Smith RR: Exosomes secreted by cardiosphere-derived cells reduce scarring, attenuate adverse remodelling, and improve function in acute and chronic porcine myocardial infarction. Eur Heart J 2016;38:201-211.

145 Wang C, Zhang C, Liu L, Xi A, Chen B, Li Y, Du J: Macrophage-derived mir-155-containing exosomes suppress fibroblast proliferation and promote fibroblast inflammation during cardiac injury. Mol Ther 2017;25:192204.

146 Wang K, Jiang Z, Webster KA, Chen J, Hu H, Zhou Y, Zhao J, Wang L, Wang Y, Zhong Z: Enhanced Cardioprotection by Human Endometrium Mesenchymal Stem Cells Driven by Exosomal MicroRNA-21. Stem Cells Transl Med 2017;6:209-222.

147 Park CY, Choi SC, Kim JH, Choi JH, Joo HJ, Hong SJ, Lim DS: Cardiac Stem Cell Secretome Protects Cardiomyocytes from Hypoxic Injury Partly via Monocyte Chemotactic Protein-1-Dependent Mechanism. Int J Mol Sci 2016;17:800.

148 Liu H, Gao W, Yuan J, Wu C, Yao K, Zhang L, Ma L, Zhu J, Zou Y, Ge J: Exosomes derived from dendritic cells improve cardiac function via activation of CD4+ T lymphocytes after myocardial infarction. J Mol Cell Cardiol 2016;91:123-133.

149 Teng X, Chen L, Chen W, Yang J, Yang Z, Shen Z: Mesenchymal stem cell-derived exosomes improve the microenvironment of infarcted myocardium contributing to angiogenesis and anti-inflammation. Cell Physiol Biochem 2015;37:2415-2424.

150 Hu X, Xu Y, Zhong Z, Wu Y, Zhao J, Wang Y, Cheng H, Kong M, Zhang F, Chen Q: A large-scale investigation of hypoxia-preconditioned allogeneic mesenchymal stem cells for myocardial repair in non-human primates: Paracrine activity without remuscularization. Circ Res 2016;118:970-983.

151 Mehmood A, Ali M, Khan SN, Riazuddin S: Diazoxide preconditioning of endothelial progenitor cells improves their ability to repair the infarcted myocardium. Cell Biol Int 2015;39:1251-1263.

152 Xu Y, Hu X, Wang L, Jiang Z, Liu X, Yu H, Zhang Z, Chen H, Chen H, Steinhoff G: Preconditioning via angiotensin type 2 receptor activation improves therapeutic efficacy of bone marrow mononuclear cells for cardiac repair. PLoS One 2013;8:e82997.

153 Hoke NN, Salloum FN, Kass DA, Das A, Kukreja RC: Preconditioning by Phosphodiesterase-5 Inhibition Improves Therapeutic Efficacy of Adipose-Derived Stem Cells Following Myocardial Infarction in Mice. Stem Cells 2012;30:326-335. 